\title{
FINANCIAL DEVELOPMENT, FINANCIAL OPENNESS, AND ECONOMIC GROWTH
}

Gemma Estrada, Donghyun Park, and Arief Ramayandi

NO. 442

August 2015
ADB ECONOMICS WORKING PAPER SERIES 
ADB Economics Working Paper Series

\section{Financial Development, Financial Openness, and Economic Growth}

Gemma Estrada, Donghyun Park, and Arief Ramayandi

No. 442 | August 2015
Gemma Estrada (gestrada@adb.org) is Senior Economics Officer, Donghyun Park (dpark@adb.org) is Principal Economist, and Arief Ramayandi (aramayandi@adb.org) is Senior Economist at the Economic Research and Regional Cooperation Department of the Asian Development Bank. 
Asian Development Bank

6 ADB Avenue, Mandaluyong City

1550 Metro Manila, Philippines

www.adb.org

(C) 2015 by Asian Development Bank

August 2015

ISSN 2313-6537 (Print), 2313-6545 (e-ISSN)

Publication Stock No. WPS157543-2

The views expressed in this paper are those of the authors and do not necessarily reflect the views and policies of the Asian Development Bank (ADB) or its Board of Governors or the governments they represent.

ADB does not guarantee the accuracy of the data included in this publication and accepts no responsibility for any consequence of their use.

By making any designation of or reference to a particular territory or geographic area, or by using the term "country" in this document, $A D B$ does not intend to make any judgments as to the legal or other status of any territory or area.

Note: In this publication, "\$” refers to US dollars.

The ADB Economics Working Paper Series is a forum for stimulating discussion and eliciting feedback on ongoing and recently completed research and policy studies undertaken by the Asian Development Bank (ADB) staff, consultants, or resource persons. The series deals with key economic and development problems, particularly those facing the Asia and Pacific region; as well as conceptual, analytical, or methodological issues relating to project/program economic analysis, and statistical data and measurement. The series aims to enhance the knowledge on Asia's development and policy challenges; strengthen analytical rigor and quality of ADB's country partnership strategies, and its subregional and country operations; and improve the quality and availability of statistical data and development indicators for monitoring development effectiveness.

The ADB Economics Working Paper Series is a quick-disseminating, informal publication whose titles could subsequently be revised for publication as articles in professional journals or chapters in books. The series is maintained by the Economic Research and Regional Cooperation Department. 


\section{CONTENTS}

TABLES AND FIGURES

ABSTRACT V V

I. WHY DO FINANCIAL DEVELOPMENT AND FINANCIAL OPENNESS MATTER? 1

II. LITERATURE REVIEW 2

A. Financial Development and Economic Growth 2

B. Financial Openness and Economic Growth 4

III. $\quad$ EMPIRICAL FRAMEWORK AND DATA 6

A. Baseline Regression 6

B. Extended Analysis $\quad 9$

IV. EMPIRICALRESULTS

A. $\quad$ Baseline Results 12

B. Evidence from Developing Countries 15

C. Degree of Financial Development and Openness 15

D. Effect of the Exchange Rate Regime 18

E. Differences between FDI and Non-FDI 18

V. CONCLUDING OBSERVATIONS

$\begin{array}{ll}\text { APPENDIXES } & 25\end{array}$

$\begin{array}{ll}\text { REFERENCES } & 37\end{array}$ 


\section{TABLES AND FIGURES}

\section{TABLES}

$1 \quad$ Baseline Results (Financial Development Indicator: Liquid Liabilities)

2 Results on Whether Effects in Developing Countries and Developing Asia Differ (Financial Development Indicator: Liquid Liabilities)

3 Results on Whether Growth Effects Vary with Level of Financial Development and Openness (Financial Development Indicator: Liquid Liabilities)

$4 \quad$ Results on Whether Foreign Exchange Rate Regimes Matter (Financial Development Indicator: Liquid Liabilities)

$5 \quad$ Baseline Results on Impact of FDI and Non-FDI on Growth

6 Results on Whether Effects of FDI and Non-FDI on Growth Differ in Developing Countries and Developing Asia

\section{FIGURES}

$1 \quad$ Liquid Liabilities and Lending-Deposit Spread $\quad 7$

$2 \quad$ Liquid Liabilities and Overhead Costs 7

3 GDP per Capita Growth and Total Openness, with Liquid Liabilities as Financial Development Indicator and Under de Facto Foreign Exchange Regimes

4 GDP per Capita Growth and Total FDI, with Liquid Liabilities as Financial Development Indicator and Under a de Facto Foreign Exchange Rate Regime

5 GDP per Capita Growth and Financial Development Measures, with Total Capital Flows as Openness Indicator and Under a de Facto Foreign Exchange Regime 


\begin{abstract}
A sound and efficient financial system is an indispensable ingredient of economic growth. It consists primarily of banks and capital markets, which channel savings into investments and other productive activities that contribute to economic growth and augment the economy's productive capacity. This paper explains the importance of financial development and openness. It sifts through the literature on the relationship between both variables and economic growth. It then reports the results and discusses some original empirical analysis. In addition to using more updated data, which extend the sample period to include some postcrisis years, the analysis examines whether country characteristics and factors such as the exchange rate regime affect the finance-growth nexus.
\end{abstract}

Keywords: economic growth, exchange rate regime, financial development, financial openness

JEL Classification: C33, E44, F31, G20 


\section{WHY DO FINANCIAL DEVELOPMENT AND FINANCIAL OPENNESS MATTER?}

A critical function of the financial system is to allocate capital to its most productive uses. Other things equal, a country with a financial system that efficiently allocates capital will grow faster than a country with a financial system that allocates capital inefficiently. The former will have more productive investments and fewer white elephants than the latter. Banks that lend on the basis of commercial merit will be far more efficient than banks that lend on the basis of personal relationships. As a country's finance sector develops, it will become better at allocating capital.

In addition to efficiently allocating resources, a sound and efficient financial system contributes to dynamic efficiency gains over time. Financing from venture capitalists and angel investors gave rise to Silicon Valley, the epicenter of the global information and communication technology (ICT) revolution. More mundanely but more importantly, the financing of entrepreneurs and smaller firms allows new players to enter the market, which spurs new and old firms to create new products and technologies.

The concept of financial openness is related to, but distinct from, the concept of financial development. As a financial system develops and becomes more sophisticated, it often opens up to foreign capital and becomes more closely integrated with foreign financial systems. (A country can also experience financial development while maintaining a relatively closed financial system, as the experience of the People's Republic of China [PRC] shows.) Financial openness can have significant effects on financial development, both positive (participation of foreign institutional investors can benefit underdeveloped Asian bond markets) and negative (instability arising from reversal of volatile short-term capital flows can set back financial development).

Intuitively, financial openness would seem to have a positive influence on economic growth. Foreign direct investment (FDI) inflows can foster growth by bringing in advanced foreign technology, managerial skills, and other knowhow and by making domestic markets more competitive through the entry of foreign companies. Even non-FDI inflows can contribute to growth, by enabling domestic firms to access foreign savings. However, in the absence of a sound and efficient financial system, foreign capital inflows may be misallocated, resulting in growth-crippling financial crisis. For all of these factors, it is worth investigating the effect of financial openness on economic growth, in addition to the effect of financial development.

The global financial crisis of 2008-2009 fueled widespread skepticism about the positive effects of financial development on economic growth and popular hostility toward the financial industry. The crisis was unprecedented in that it originated in and almost paralyzed the financial systems of the advanced economies. When the crisis spread to the real economy, it wrought havoc on global trade and growth and caused the world economy to contract, albeit marginally, for the only time in the postwar era.

Superficially, the most obvious lesson from the crisis might be that too much financial development and innovation can be harmful for financial stability and growth. After all, complex and sophisticated financial innovations such as mortgage-backed securities, structured investment vehicles, and collateralized debt obligations were the catalysts of the crisis.

The global financial crisis intensified but did not initiate doubts about whether financial development is beneficial for growth. Such doubts are consistent with empirical studies that reveal a nonlinear relationship between the two variables. These studies find that financial development 
contributes to economic growth-but only up to a point, after which it may even adversely affect growth. The global financial crisis is consistent with such evidence.

Concerns about too much financial development and the deleterious effect of finance on growth are much more relevant for advanced countries than developing countries. The complex financial innovations of global financial centers such as New York and London are a world away from financially underdeveloped Asia, which remains well inside the global finance frontier. For Asian countries, financial development does not refer to mortgage-backed securities, structured investment vehicles, or collateralized debt obligations but rather to the much more basic task of building sound and efficient financial systems that allocate capital to their most productive uses. In light of the vast gap between the financial development levels of Asia and the advanced economies, the wrong lesson for Asian countries to draw from the global financial crisis is that they should halt or slow down financial development.

Financial innovation is not without its risks, but financial underdevelopment carries risks of its own-as the region learned at great cost during the Asian crisis. Because financial development means fundamentally different things to advanced economies and developing countries, its effect on growth may differ for the two groups of countries. The returns to financial development are likely to be higher in developing countries, which stand to reap large efficiency gains (fewer white elephants and more productive gains) as their banks and capital markets develop from low initial bases.

\section{LITERATURE REVIEW}

Several studies indicate that the depth of the financial system has a significant positive impact on growth. In particular, a larger financial system-as measured by liquid liabilities, private credit, and stock market capitalization-is associated with higher growth.

On financial openness, studies yield mixed results. Limited evidence indicates that greater financial openness leads to higher growth.

\section{A. Financial Development and Economic Growth}

The literature includes four types of studies on the finance-growth relationship (Demirgüç-Kunt and Levine 2008):

(i) pure cross-country growth regressions,

(ii) panel techniques that use both the cross-country and time-series dimensions of the data,

(iii) microeconomic studies that explore the various channels through which finance may affect economic growth, and

(iv) individual country case studies.

The first approach involves the application of broad cross-country growth regressions, which seek to explain growth through standard explanatory variables such as physical and human capital. These studies typically aggregate growth over long periods of time and examine the relationship between long-run growth and various measures of financial development. The second approach analyzes panel data, in an effort to mitigate some of the econometric problems associated with the pure cross-country approach. It has a number of advantages over the first approach, although it also 
suffers from some disadvantages. The third approach uses firm- and industry-level data to assess the impact of financial development on firm and industry performance. A positive impact would lend support to the notion that financial development is beneficial for growth. The fourth approach looks at the finance-growth relationship in a single country, usually with the aim of analyzing the impact of a specific policy change.

We focus on studies that apply cross-country growth regressions, including studies that use panel techniques, because this is the approach we used in our own empirical analysis. In earlier crosscountry regression studies, economic growth is usually averaged over long periods, while financial indicators are either averaged over the same period or taken from the initial year. Several macroeconomic indicators are used as control variables.

One of the earliest studies of this type is by King and Levine (1993), who examine the relationship between financial depth (as measured by liquid liabilities) and three growth measures (real per capita gross domestic product (GDP) growth, real per capita capital stock growth, and total productivity growth), all averaged over the sample period. Using data for 77 countries over the period 1960-89, they find a statistically significant positive relationship between financial depth and the three growth measures.

Levine and Zervos (1998) analyze data for 47 countries over the period 1976-1993. They find the initial level of banking development and stock market activity to have statistically significant relationships with average output growth, capital stock growth, and productivity growth.

Beck and Levine (2004) apply panel econometric techniques to new data to reexamine the relationship between stock markets, banks, and economic growth. They study whether measures of stock market and bank development have positive relationships with economic growth after controlling for simultaneity and omitted variable bias. They use data for 40 countries, over the period 1976-98, employing generalized method of moments estimators. They find that stock markets and banks are jointly significant in affecting economic growth, suggesting that stock markets and banks provide different financial services.

Bekaert, Harvey, and Lundblad (2005) examine financial development and financial openness, using equity market turnover and private credit as measures of financial development and equity market liberalization as an indicator of financial openness. They find that equity market liberalization led to a $1 \%$ increase in annual economic growth over a 5 -year period. Liberalization of the equity market has two effects. First, it directly reduces financing constraints, as more foreign capital becomes available. Second, it improves corporate governance, as a result of the increase in investment. The presence of financial development variables does not knock out the liberalization effect.

Cihak et al. (2012) use an updated version of the global financial development database to replicate the model of King and Levine (1993). They find similar growth-enhancing effects of financial development.

In their review of the literature, Demirgüç-Kunt and Levine (2008) note that weaknesses in measures of financial development remain. No measure adequately captures the ability of the financial system to provide financial services that facilitate the screening of firms before they are financed; the monitoring of firms after they are financed; the management of both idiosyncratic project risk and liquidity risk; or the exchange of goods, services, and financial claims. As a result, it is difficult to design suitable empirical proxies of financial development. Empirical studies-including our own and studies 
by Rajan and Zingales (1998), Levine and Zervos (1998), and Demirgüç-Kunt and Levine (2008)thus rely on traditional measures of financial development.

\section{B. Financial Openness and Economic Growth}

Various indicators have been developed to measure financial openness and integration. These indicators are often classified as de jure, de facto, and hybrid measures. The main source for most de jure indicators is the Annual Report on Exchange Rate Arrangements and Exchange Restrictions, published by the International Monetary Fund (IMF), which provides information on the extent and nature of rules and regulations governing external account transactions for a wide array of countries. These data have been widely used as the basis for binary measures of capital controls and financial openness (Alesina, Grilli, and Milesi-Ferretti 1994; Edison et al. 2004).

Quinn, Schindler, and Toyoda (2011) survey a wide range of indicators on financial openness, identifying their properties and how the indicators relate to one another. Among de jure measures, the KAOPEN index by Chinn and Ito (2008) and the financial openness index (FOI) by Johnston and Tamirisa (1998), and Brune and Guisinger (2006) cover the broadest range of countries and time periods. Chinn and Ito's index measures the extent of openness or restrictions in cross-border financial transactions. It is constructed using principal component analysis on four variables: the presence of multiple exchange rates, restrictions on current account transactions, restrictions on capital account transactions, and the requirement of the surrender of export proceeds.

The FOI represents the cumulative total of the binary score for 12 categories. It distinguishes between inward and outward flows and resident and nonresident transactions. It decomposes the subcomponents of capital flows in fine detail. Unlike Chinn and Ito's index, the indicators are not publicly available.

Both KAOPEN and the FOI are ideal for aggregate information. If a more disaggregated measure is needed, Schindler's (2009) index may be better suited, although its sample size is smaller. Unlike other indexes, Schindler's (2009) index provides binary codes at the level of individual types of transactions. In addition, indexes can be created by asset category, residency status, and inflows versus outflows, allowing for an analysis in line with the balance of payments focus on residency as well as based on the direction of capital flows.

De jure measures are beset by limitations. They do not always reflect the actual degree of financial integration of an economy into international capital markets, as other regulations that restrict capital are not considered as such. In addition, these measures do not capture the degree of enforcement of capital controls (Quinn and Toyoda 2008; Quinn, Schindler, and Toyoda 2011; Kose et al. 2009).

An alternative way to measure financial integration is to use de facto indicators. Quantitybased measures that rely on actual flows best capture de facto integration for emerging markets and low-income developing countries. Gross flows (the sum of total inflows and total outflows) are preferred over net flows, because they provide a less volatile and more accurate picture of integration. Because gross flows tend to be volatile and prone to measurement error, however, the sum of gross stocks of foreign assets and liabilities should be expressed as a share of GDP (Kose et al. 2009). A widely used de facto indicator is Lane and Milesi-Ferreti's $(2006,2007)$ index, which is calculated as a country's aggregate assets plus liabilities relative to its GDP. This measure includes portfolio equity, FDI, debt, and financial derivatives. 
An important limitation of de facto indicators is the inconsistent reporting and treatment of FDI across countries and over time. De facto measures may also fail to accurately reflect a government's policy stance. Some firms may invest in some countries because of capital account restrictions. De jure restrictions can thus affect capital flows.

Comparing both de jure and de facto indicators, Kose et al. (2009) find that average de jure openness did not change much over the last 2 decades but de facto integration increased dramatically. This finding reflects the fact that the information in the two types of integration can differ. It is important to take these differences into account.

Studies of the relationship between financial openness and growth reveal mixed results or provide little evidence on developing countries (Kose et al. 2009; Obstfeld 2009; Quinn and Toyoda 2008; Quinn, Schindler, and Toyoda 2011). Differences in the type of openness measure, the sample period, country coverage, and the choice of empirical methodology are the main reasons for the diverse findings in the literature.

The positive relationship between capital account liberalization and growth appears to have declined over time, as studies undertaken using data from the 1980s and 1990s or 1960s-1990s are more likely to indicate a positive effect than studies undertaken more recently. Another issue that weakens results is endogeneity - the fact that countries may decide to open their finance sector when growth prospects become more favorable (Bartolini and Drazen 1997; Rodrik 1998). Changes in the policy environments or institutions that simultaneously drive additional reforms may also affect financial openness.

Finding robust evidence that financial integration systematically increases growth has remained difficult. But studying longer time periods, researchers have found a positive link between the two variables, especially when financial integration is measured using de facto or finer de jure measures and interaction terms accounting for supportive conditions such as good policies and institutions are properly included.

Despite limited evidence, countries have pursued greater financial openness, as a growing finance sector cannot afford to be insulated from cross-border financial flows. Financial opening is likely to promote a more competitive and resilient domestic financial system. Financial liberalization can yield collateral benefits that spur growth and make an open financial account less prone to crises.

For financial openness to generate growth benefits, however, a well-developed and wellsupervised finance sector, good institutions, and sound macroeconomic policies need to be in place (Kose et al. 2009). Countries are more likely to gain from financial openness when it is implemented in a phased manner, starting with an opening up to FDI, which has the biggest positive effect on domestic investment and growth. This step may be followed by liberalizing portfolio equity flows, in parallel with a growing local financial market. Restrictions on longer-term debt flows can then be eased. Shortmaturity flows should be liberalized last (Obstfeld 2009). 


\section{EMPIRICAL FRAMEWORK AND DATA}

This section lays out the econometric framework used in our empirical analysis. It also describes the data used.

\section{A. Baseline Regression}

The general approach in the literature is to estimate growth regressions that explicitly include financial development and openness in the set of determinants of economic growth. The basic structure of the regression equation is as follows:

$$
Y_{i, t}=\alpha+\beta_{1}[F D]_{i, t}+\beta_{2}[F O]_{i, t}+\gamma[E R]_{i, t}+\lambda[\text { Other }]_{i, t}+v_{i}+\varepsilon_{i, t}
$$

where financial development [FD] indicators, measures of financial openness [FO], the exchange rate regime $[E R]$, and a number of nonfinancial control variables [Other] are assumed to affect economic growth $(Y)$. For measures of economic growth, we use a series of nonoverlapping 5-year average of GDP per capita growth for each of the sample countries. The depth of the finance sector is commonly used as an empirical proxy for financial development. The notion of financial development, however, goes beyond mere depth. A more developed finance sector is expected to promote economic growth through its greater efficiency in channeling funds to support economic activities. Financial efficiency can be gauged by lending-deposit spreads and banks' overhead costs, which are lower in broader and more advanced financial systems. 'Data on these indicators tend to be more limited than data on financial depth.

The relationship between lending-deposit spreads and liquid liabilities (Figure 1) and overhead costs and liquid liabilities (Figure 2) is somewhat curvilinear. Lower lending-deposit spreads and overhead costs are associated with larger finance sectors, confirming the widely held view that deeper financial markets tend to be more efficient. This relationship may justify the use of financial depth indicators as proxies for financial development. We use three indicators of financial development in this paper:

(i) Total liquid liabilities as a share of GDP measures relative overall financial depth. It consists of currency plus demand and interest-bearing liabilities of banks and nonbank financial intermediaries. It is the broadest measure of financial intermediation activity, as it covers all banks, central banks, and nonfinancial intermediary activities.

(ii) Private credit by deposit money banks as a share of GDP isolates the impact of the banking sector.

(iii) Stock market capitalization as a share of GDP gauges the relative size of the equity market in an economy.

Data on liquid liabilities come from the Financial Development and Structure Dataset of Beck, Demirgüç-Kunt, and Levine (2000, 2009); and Cihak et al. (2012), which was updated in November 2013. Data on private credit and stock market capitalization come from the World Bank's World Development Indicators online database.

\footnotetext{
See the Financial Development and Structure Dataset (Beck, Demirgüç-Kunt, and Levine 2000, 2009; Cihak et al. 2012).
} Data on lending-deposit spreads are available for 1980-2011. Data on overhead costs are available for 1998-2011. 

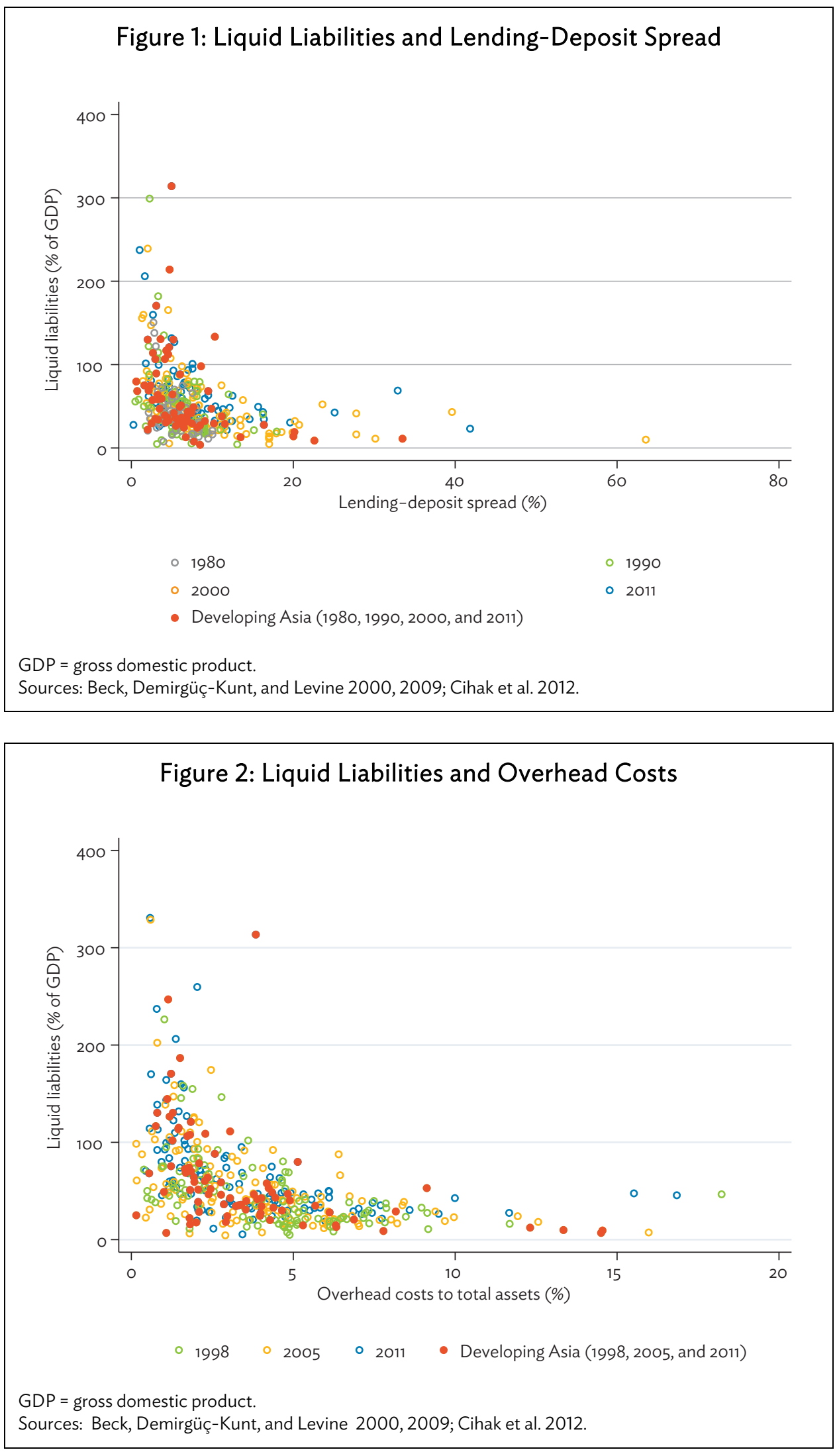
We rely on three measures of financial openness, two de facto and one de jure indicator. The first de facto measure is total capital flows as a share of GDP. This measure is the sum of inflows and outflows of direct investment, equity investment, debt securities, financial derivatives, and other investment. It accounts for capital account transactions of both residents and nonresidents in a given year.

The second de facto measure is the updated and extended version of a dataset constructed by Lane and Milesi-Ferretti (2007), which includes data for 188 countries. This widely used de facto indicator is calculated as a country's aggregate assets plus liabilities as a share of its GDP. It includes portfolio equity, FDI, debt, and financial derivatives. The dataset employs a common methodology to construct estimates of foreign asset and liability positions of a large set of countries, relying on both direct measures of stocks and cumulative flows with valuation adjustments. For most countries, the benchmark used is the official international investment position (IIP) estimates for recent years. Lane and Milesi-Ferretti then work backward with data on capital flows and estimates for capital gains and losses to calculate stock positions for earlier years. Recognizing the large cross-country variation in the reliability of data on capital flows and estimated stock positions, they use various techniques to derive the most suitable series for each country.

The third type of capital openness measure is the de jure index constructed by Chinn and Ito (2008). Their measure of the extent of openness uses data from the IMF's Annual Report on Exchange Rate Arrangements and Exchange Restrictions, which provides information on the extent and nature of rules and regulations governing external account transactions for a wide array of countries.

For exchange rate regimes, we consider both the de facto classification and the official IMF classification constructed by Reinhart and Rogoff (2004) and updated by Ilzetski, Reinhart, and Rogoff (2011). The de facto classification starts by using country chronologies to identify countries with official, dual, or multiple rates or active parallel (black) markets. In the absence of a dual or parallel market, the authors check any official preannounced arrangement and verify it by examining exchange rate movements. If there is no preannounced exchange rate regime or the announced regime cannot be verified by data and the 12 -month inflation rate is below $40 \%$, they classify a country by examining the exchange rate behavior. Their judgment is based on exchange rate variability of monthly observations (measured through mean absolute change), averaged over 2-year and 5-year rolling windows. To determine whether exchange rate changes are kept within a band, they calculate the probabilities that the exchange rate remains within $+/-1,2$, and $5 \%$ bands over 2 -year and 5 -year rolling windows.

Countries are classified as de facto free falling on the basis of two criteria. One is having a 12month rate of inflation of at least $40 \%$, unless the regime can be classified as a preannounced peg or preannounced narrow band. The other is whether in the 6 months following a currency crisis the country moves from a fixed or quasi-fixed regime to a managed or independently floating regime or a large change in the exchange rate reflects a loss of credibility and persistent speculative attacks rather than a policy change.

Reinhart and Rogoff (2004) and Ilzetski, Reinhart, and Rogoff (2011) construct the official IMF classification based on the information submitted by member-countries and reported in the Annual Report on Exchange Rate Arrangements and Exchange Restrictions. The coarse classifications are recategorized into four regimes: fixed, managed, flexible, and freely falling or dual markets with missing parallel market data (Appendix Table A1). The regimes follow the initial year of each 5-year period.

Several control variables are included to account for other factors affecting growth. The choice of these variables closely follows the variables used in many growth regression analyses (Levine and 
Zervos 1998; Beck, Levine, and Loayza 2000; Edison et al. 2002). Initial GDP per capita from the World Bank's World Development Indicators online database is included to account for the growth convergence effect. Years of schooling from Barro and Lee (2010) are included to represent impact of human capital accumulation on growth. Other standard growth determinants controlled for include relative trade openness, inflation, and government consumption, all taken from the World Development Indicators online database. The control variables were averaged for each 5-year period, except initial GDP, for which the value at $t-5$ is used.

Appendix Table A2 shows the correlation coefficients for an initial examination of the associations among variables, especially financial development, financial openness, and growth. It shows positive correlations between measures of financial development and growth, which are higher than the correlations between measures of financial openness and growth.

For the empirical estimation, we apply the Arellano-Bond generalized method of moments to the panel dataset. The full sample of the GDP per capita growth regression is a cross-country panel dataset covering 108 economies (of which 20 are developing Asian economies) with five nonoverlapping 5-year periods between 1977 and 2011. ${ }^{2}$ Arellano and Bond (1991) suggest firstdifferencing the regression equation to eliminate the country-specific effect, as follows:

$$
\Delta Y_{i, t}=\Delta \beta_{1}[F D]_{i, t}+\Delta \beta_{2}[F O]_{i, t}+\Delta \gamma[E R]_{i, t}+\Delta \lambda[\text { Others }]_{i, t}+\Delta u_{i, t}
$$

where $\Delta u_{i, t}=\Delta v_{i}+\Delta \varepsilon_{i, t}=\left(v_{i}-v_{i}\right)+\left(\varepsilon_{i, t}-\varepsilon_{i, t-1}\right)=\left(\varepsilon_{i, t}-\varepsilon_{i, t-1}\right)$.

First-differencing removes the fixed country-specific effect. The first-differenced dependent variables, which are assumed to be endogenous, can then be instrumented with their past levels. The estimation method addresses possible endogeneity problems that arise because of the possibility of a two-way causation between financial development and openness.

The equation represents our baseline regression, which includes the financial development and openness indicators, the exchange rate regime dummies, and the standard determinants of growth used in empirical growth regressions. The main focus of the analysis is the effect of financial development and financial openness on economic growth. Other explanatory variables are included to control for their influence on the growth rate.

\section{B. Extended Analysis}

We extend the analysis by asking several additional questions. Is the growth effect of the financial variables different for developing countries? Would a different level of financial openness or development alter the effect of the other financial variables on growth? Does the foreign exchange regime interfere with the way financial variables affect economic growth?

Partial scatter plots of these indicators show the marginal contribution of openness or financial development indicator to GDP per capita growth while controlling for other variables in the model. GDP per capita growth, openness, and financial development indicators are regressed against the other predictor variables, and the residuals are obtained from each estimation. Estimations were done using pooled panel regressions. The residuals from regressing GDP per capita growth against the other

2 Appendix Table A3 lists the economies included in the regressions. The 5-year periods are 1977-1981, 1982-1986, 19871991, 1992-1996, 1997-2001, 2002-2006, and 2007-2011. 
explanatory variables are shown on the vertical axis; the residuals from regressing openness or financial development against the other variables are shown on the horizontal axis. The plots are used to identify the nature of the relationship between two indicators given the effect of the other independent variables in the model. We first explored the plots using separate models for de facto foreign exchange regime and de jure foreign exchange regime. As plots in both types of regime show strong resemblance, we show only the plots with de facto regimes.

We investigate the likely relationship using the three measures of openness: total capital flows, Lane and Milesi-Ferretti's openness measure, and Chinn and Ito's openness indicator (Figure 3). The plot for total capital flows indicates a flat marginal contribution from openness, indicating no clear positive or negative linear relationship. When Lane and Milesi-Ferretti's openness measure is used, an apparent negative linear relationship is seen. As with total capital flows, Chinn and Ito's measure does not show a clear negative or positive linear association with output growth.

Figure 3: GDP per Capita Growth and Total Openness, with Liquid Liabilities as Financial Development Indicator and Under de Facto Foreign Exchange Regimes
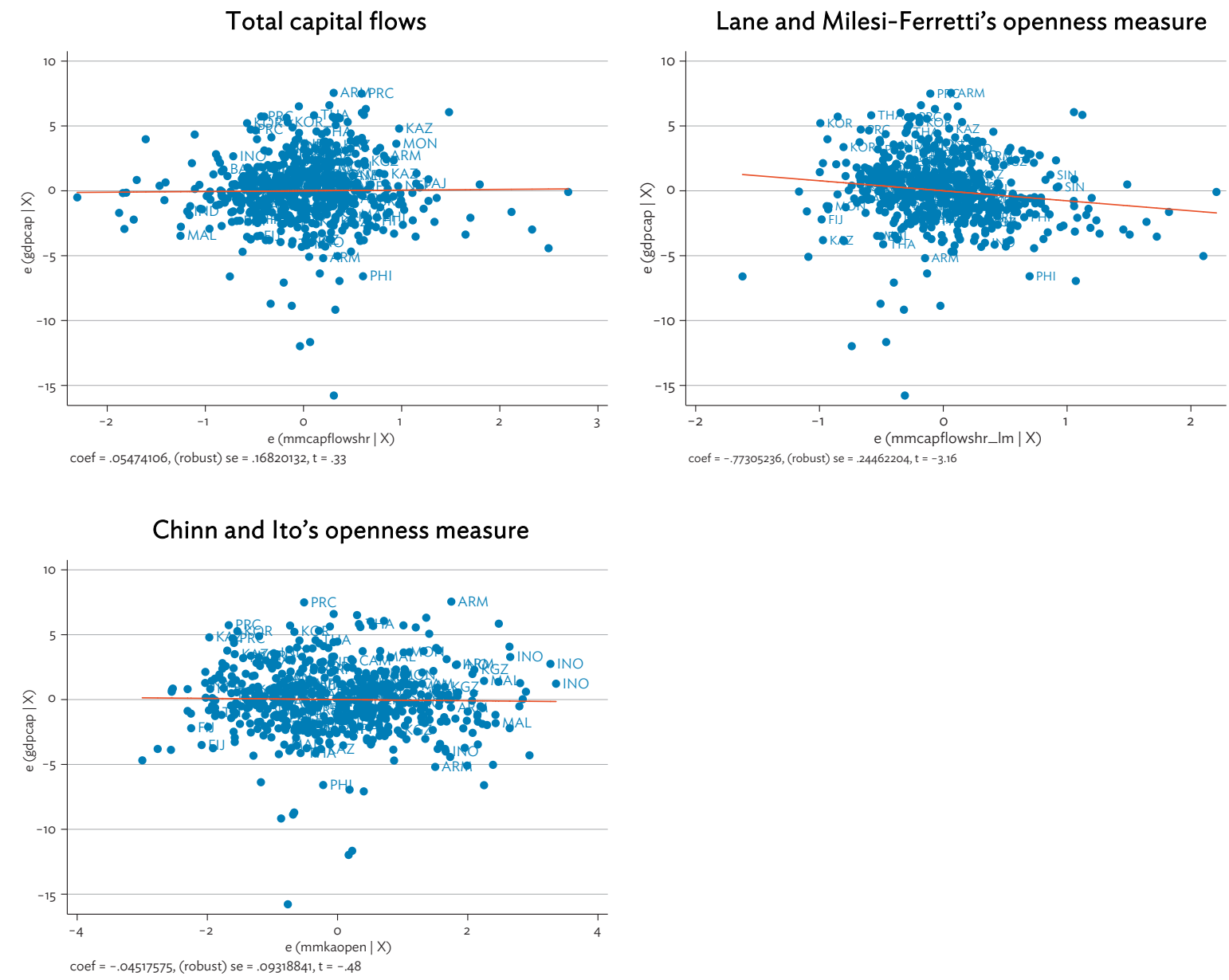

GDP = gross domestic product.

Note: See Appendix Table A3 for the country abbreviations.

Source: Authors' estimates based on data from Chinn and Ito (2008); Lane and Milesi-Ferretti (2007); Reinhart and Rogoff (2004); Ilzetski, Reinhart, and Rogoff (2011); and World Bank, World Development Indicators online database (accessed 15 September 2014). 
We perform the same analysis for FDI and non-FDI flows, using computed total flows and Lane and Milesi-Ferretti's measure (Figure 4). The residuals for FDI indicate a positive linear pattern when using total flows data. The trend is not evident when using Lane and Milesi-Ferretti's measure. An almost flat pattern is seen for total non-FDI flows, suggesting no clear positive or negative linear association. With Lane and Milesi-Ferretti's measure of non-FDI, there is an obvious negative linear relationship.

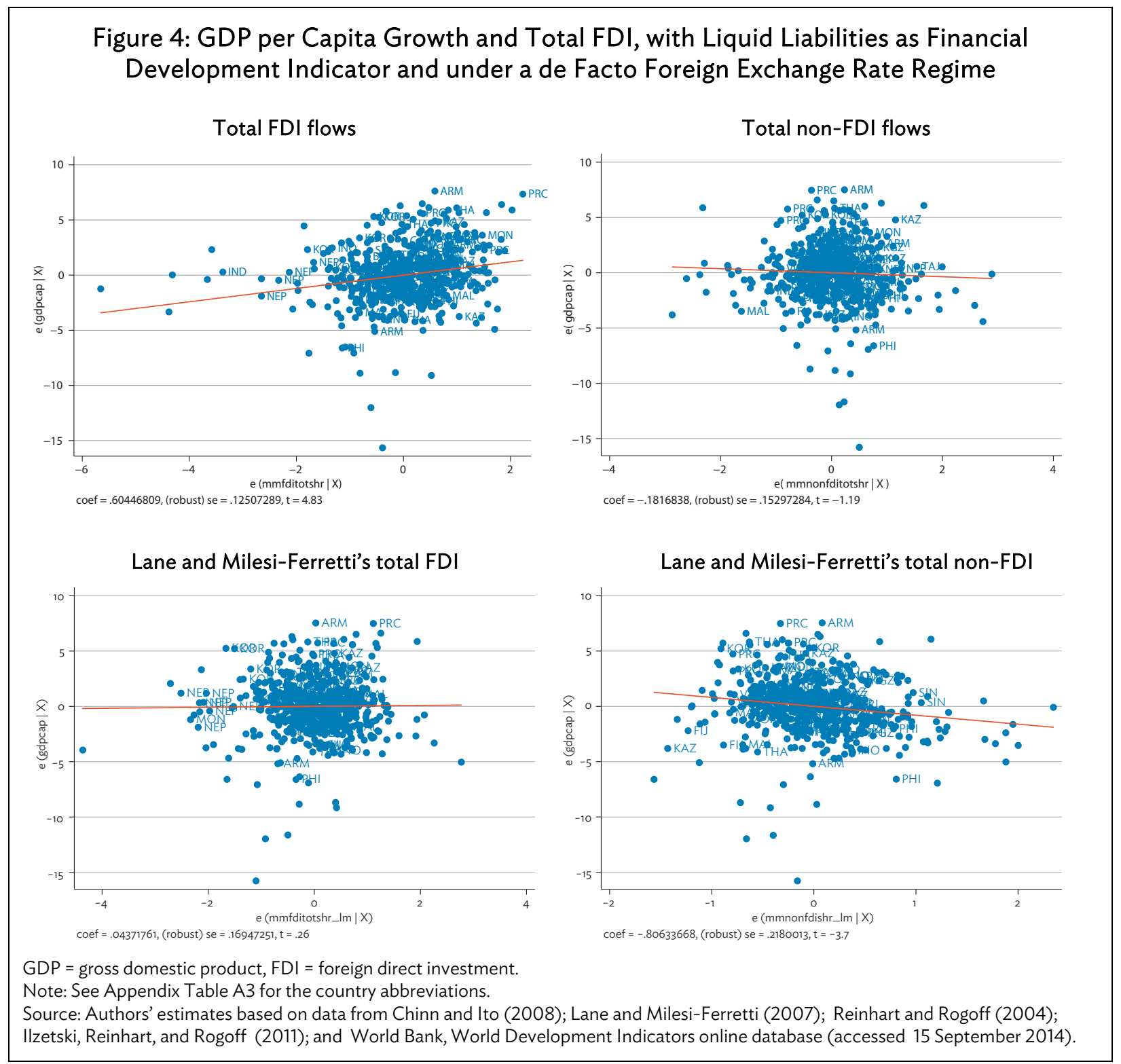

For financial development, we use data on liquid liabilities, private credit, and stock market capitalization (Figure 5). The plots indicate that growth is positively associated with liquid liabilities and private credit. There is no clear relationship between output growth and stock market capitalization.

There appears to be an outlier, which has a residual of less than -15 from the growth regression. Removing it from the sample does not strongly influence the nature of the relationship between the variables. 
Figure 5: GDP per Capita Growth and Financial Development Measures, with Total Capital Flows as Openness Indicator and under a de Facto Foreign Exchange Regime
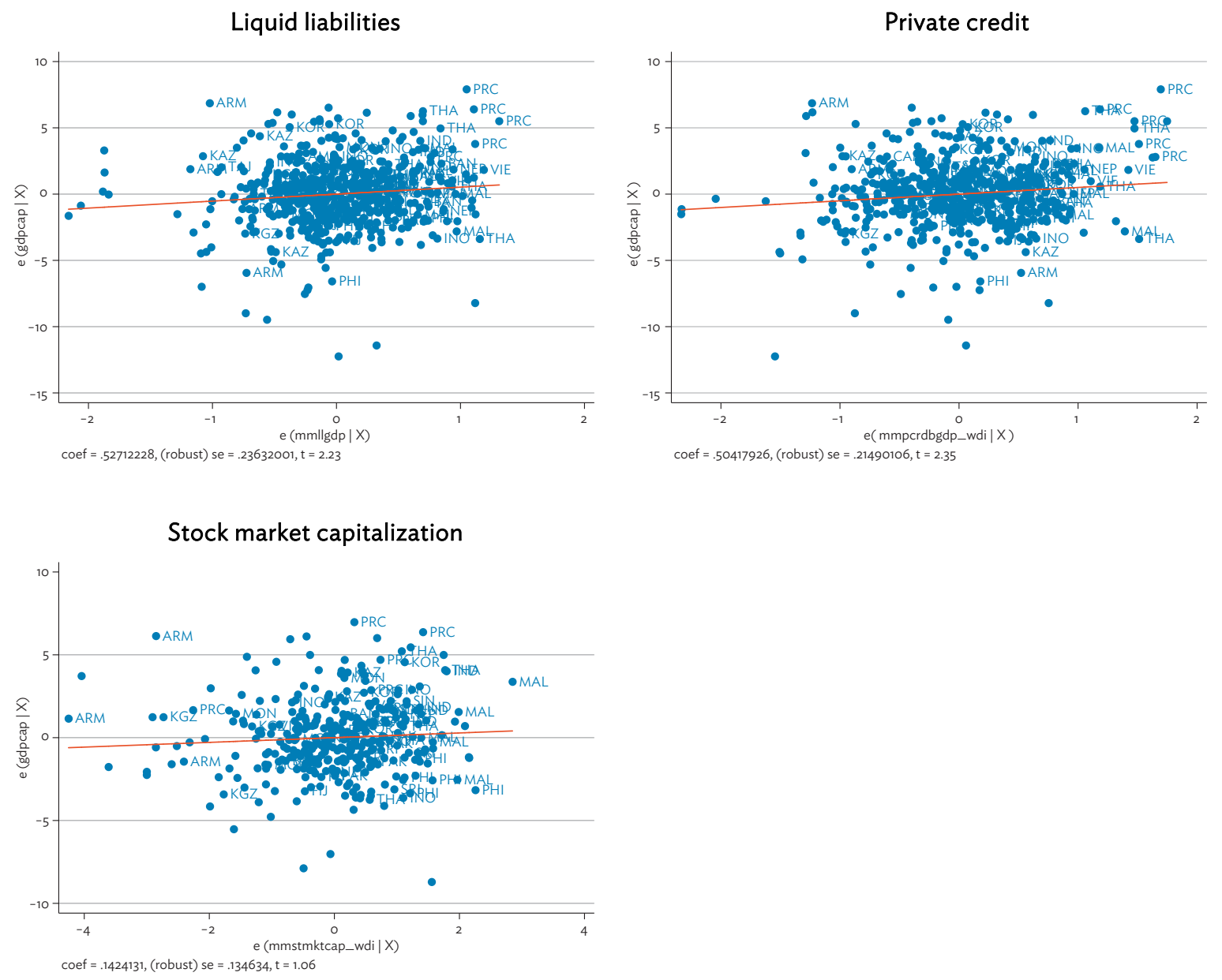

GDP = gross domestic product.

Note: See Appendix Table A3 for the country abbreviations.

Source: Authors' estimates based on data from Chinn and Ito (2008); Lane and Milesi-Ferretti (2007); Reinhart and Rogoff (2004);

Ilzetski, Reinhart, and Rogoff (2011); and World Bank, World Development Indicators online database (accessed 15 September 2014).

\section{EMPIRICAL RESULTS}

Correlations and scatter plots are useful in understanding the relationships between growth and openness measures and between growth and financial development. A more rigorous analytical method is required to assess the robustness of such relationship. This section presents our results from applying the Arellano-Bond generalized method of moments estimation.

\section{A. Baseline Results}

Table 1 displays the results of our baseline regressions. They are consistent with economic intuition as well as the findings of the previous empirical literature. We apply time dummies to account for possible unobserved heterogeneity across time in the sample. 
The results on the standard determinants of growth are consistent with the empirical findings in the growth literature, with the coefficients relatively stable over different regression specifications. Initial per capita GDP exhibits negative and significant effect on growth of GDP per capita, suggesting conditional convergence. Trade has the expected significant and positive signs: per capita economic growth is higher in countries that are more open to trade. Inflation and government size tend to affect growth negatively, suggesting that macroeconomic instability and smaller private sector involvement in economic activities could be harmful for medium- to long-term growth. The findings are qualitatively similar to those of Estrada, Park, and Ramayandi (2010), who apply a panel fixed effects approach. We find, however, that the year of schooling variable has an insignificant effect on medium- to long-term growth. This result is similar to the findings of Quinn and Toyoda (2008), who use the same indicator in their growth regressions using panel data. These results are robust over alternative regression specifications.

The level of financial development, as represented by the level of a country's liquid liabilities relative to its GDP, is positive and significant for all of the specifications reported in Table 1 (also positive and significant are the relative size of private sector credit to GDP [see Appendix Table A4.1] and the relative size of stock market capitalization to GDP [see Appendix Table A5.1]). These findings suggest that our estimated parameters are robust. Our findings are very much in line with the empirical literature that suggests that financial development-as measured by financial depth-leads to higher growth. They also suggest that both the banking sector and capital markets are beneficial for growth. Regardless of its structure, overall financial development always contributes to economic growth. Therefore, deepening the finance sector should always be on the agenda of progrowth policy makers.

The actual level of financial openness also appears to have direct positive and significant effects on economic growth. This finding holds for both the total volume and the Lane and MilesiFerretti measure of capital flows. In contrast, the de jure measure of capital flows by Chinn and Ito does not appear to have significant effects on growth. Although the evidence about the link between economic growth and financial openness is inconclusive, our results suggest that a country's commitment to open domestic finance sector does not necessarily foster economic growth until it actually facilitates flows of capital to the economy. ${ }^{3}$

Our results also provide insights into whether different exchange rate regimes matter for growth. We use two definitions of exchange rate regimes, the de jure one based on the IMF classification and the de facto one constructed by Ilzetski, Reinhart, and Rogoff. For our sample, the two definitions differ substantially. The IMF definition includes no observation of free falling currency regimes; the Ilzetski, Reinhart, and Rogoff definition does.

There is no robust evidence on the effect of exchange rate regimes on growth, although there are some indications of a consistent negative association between a flexible exchange rate regime under the IMF classification and growth. The negative and significant coefficients of the flexible exchange rate regime under the IMF classifications may capture the fact that many developed countries in the sample, which tend to have lower growth rates, adopted flexible exchange rate regimes. It may also reflect the fact that the larger number of exchange rate fluctuations in countries adopting flexible exchange rate regimes may create more uncertainty, which reduced their growth potential.

3 See, for example, the discussion in Kose et al. (2009), and Bussière and Fratzscher (2008). 
Table 1: Baseline Results (Financial Development Indicator: Liquid Liabilities)

\begin{tabular}{|c|c|c|c|c|c|c|}
\hline \multirow[b]{2}{*}{ Variable } & \multicolumn{3}{|c|}{$\begin{array}{l}\text { Ilzetski, Reinhart, and Rogoff de facto } \\
\text { Indicator }\end{array}$} & \multicolumn{3}{|c|}{ IMF de jure Indicator } \\
\hline & $\begin{array}{l}\text { Total } \\
\text { Capital } \\
\text { Flows }\end{array}$ & $\begin{array}{l}\text { Lane and Milesi- } \\
\text { Ferretti }\end{array}$ & $\begin{array}{l}\text { Chinn } \\
\text { and Ito }\end{array}$ & $\begin{array}{l}\text { Total Capital } \\
\text { Flows }\end{array}$ & $\begin{array}{l}\text { Lane and Milesi- } \\
\text { Ferretti }\end{array}$ & $\begin{array}{l}\text { Chinn } \\
\text { and Ito }\end{array}$ \\
\hline & $(1)$ & $(2)$ & (3) & (4) & $(5)$ & (6) \\
\hline Financial openness & $\begin{array}{l}2.146^{* * *} \\
(0.714)\end{array}$ & $\begin{array}{l}2.244^{* * *} \\
(0.849)\end{array}$ & $\begin{array}{l}-0.255 \\
(0.309)\end{array}$ & $\begin{array}{l}2.250^{* * *} \\
(0.696)\end{array}$ & $\begin{array}{l}2.475^{* * *} \\
(0.844)\end{array}$ & $\begin{array}{l}-0.171 \\
(0.295)\end{array}$ \\
\hline $\begin{array}{l}\text { Liquid liabilities (\% of } \\
\text { GDP) }\end{array}$ & $\begin{array}{l}2.723^{* *} \\
(1.360)\end{array}$ & $\begin{array}{l}2.778^{*} \\
(1.534)\end{array}$ & $\begin{array}{l}3.033^{* *} \\
(1.484)\end{array}$ & $\begin{array}{l}2.612^{* *} \\
(1.296)\end{array}$ & $\begin{array}{l}2.854^{*} \\
(1.485)\end{array}$ & $\begin{array}{l}2.797^{*} \\
(1.434)\end{array}$ \\
\hline $\begin{array}{l}\text { Initial real per capita } \\
\text { GDP }\end{array}$ & $\begin{array}{r}-12.53^{* * *} \\
(1.679)\end{array}$ & $\begin{array}{r}-13.14^{* * *} \\
(1.528)\end{array}$ & $\begin{array}{c}-11.75^{* * *} \\
(1.502)\end{array}$ & $\begin{array}{c}-12.46^{* * *} \\
(1.688)\end{array}$ & $\begin{array}{r}-13.18^{* * *} \\
(1.527)\end{array}$ & $\begin{array}{c}-11.85^{* * *} \\
(1.461)\end{array}$ \\
\hline $\begin{array}{l}\text { Government spending } \\
\text { (\% of GDP) }\end{array}$ & $\begin{array}{r}-2.843^{* * *} \\
(1.003)\end{array}$ & $\begin{array}{l}-1.785^{*} \\
(0.984)\end{array}$ & $\begin{array}{l}-2.110^{* *} \\
(0.921)\end{array}$ & $\begin{array}{l}-3.051^{1 * *} \\
(0.992)\end{array}$ & $\begin{array}{l}-2.138^{* *} \\
(0.992)\end{array}$ & $\begin{array}{l}-2.300^{* *} \\
(0.899)\end{array}$ \\
\hline Inflation & $\begin{array}{r}-1.570^{* * *} \\
(0.484)\end{array}$ & $\begin{array}{l}-1.382^{* * *} \\
(0.427)\end{array}$ & $\begin{array}{l}-1.762^{* * *} \\
(0.415)\end{array}$ & $\begin{array}{l}-1.668^{* * *} \\
(0.433)\end{array}$ & $\begin{array}{l}-1.478^{* * *} \\
(0.390)\end{array}$ & $\begin{array}{l}-1.556^{* * *} \\
(0.375)\end{array}$ \\
\hline Years of schooling & $\begin{array}{l}-0.548 \\
(2.769)\end{array}$ & $\begin{array}{l}0.957 \\
(3.051)\end{array}$ & $\begin{array}{l}-1.766 \\
(2.196)\end{array}$ & $\begin{array}{c}0.334 \\
(2.843)\end{array}$ & $\begin{array}{c}1.581 \\
(3.120)\end{array}$ & $\begin{array}{l}-1.624 \\
(2.184)\end{array}$ \\
\hline $\begin{array}{l}\text { Trade openness (\% of } \\
\text { GDP) }\end{array}$ & $\begin{array}{r}1.601^{*} \\
(0.888)\end{array}$ & $\begin{array}{l}1.905^{* *} \\
(0.955)\end{array}$ & $\begin{array}{l}2.922^{* * *} \\
(0.811)\end{array}$ & $\begin{array}{l}1.842^{* *} \\
(0.924)\end{array}$ & $\begin{array}{l}2.003^{* *} \\
(1.003)\end{array}$ & $\begin{array}{l}2.950^{* * *} \\
(0.830)\end{array}$ \\
\hline $\begin{array}{l}\text { Managed exchange rate } \\
\text { regime }\end{array}$ & $\begin{array}{c}0.344 \\
(0.349)\end{array}$ & $\begin{array}{c}0.173 \\
(0.354)\end{array}$ & $\begin{array}{l}-0.0321 \\
(0.415)\end{array}$ & $\begin{array}{l}-0.186 \\
(0.335)\end{array}$ & $\begin{array}{l}-0.137 \\
(0.314)\end{array}$ & $\begin{array}{l}-0.216 \\
(0.305)\end{array}$ \\
\hline $\begin{array}{l}\text { Flexible exchange rate } \\
\text { regime }\end{array}$ & $\begin{array}{r}-0.0623 \\
(0.627)\end{array}$ & $\begin{array}{c}0.177 \\
(0.755)\end{array}$ & $\begin{array}{c}0.162 \\
(0.629)\end{array}$ & $\begin{array}{l}-0.710^{*} \\
(0.385)\end{array}$ & $\begin{array}{l}-0.705^{*} \\
(0.373)\end{array}$ & $\begin{array}{l}-0.711^{*} \\
(0.375)\end{array}$ \\
\hline $\begin{array}{l}\text { Free falling/dual } \\
\text { exchange rate regime }\end{array}$ & $\begin{array}{c}0.545 \\
(0.772)\end{array}$ & $\begin{array}{c}0.276 \\
(0.807)\end{array}$ & $\begin{array}{c}0.629 \\
(0.778)\end{array}$ & & & \\
\hline Period 2 & $\begin{array}{l}-0.159 \\
(0.553)\end{array}$ & $\begin{array}{l}-1.117 \\
(0.699)\end{array}$ & $\begin{array}{l}-0.273 \\
(0.447)\end{array}$ & $\begin{array}{l}-0.237 \\
(0.555)\end{array}$ & $\begin{array}{l}-1.250^{*} \\
(0.702)\end{array}$ & $\begin{array}{l}-0.182 \\
(0.437)\end{array}$ \\
\hline Period 3 & $\begin{array}{r}0.482 \\
(0.921)\end{array}$ & $\begin{array}{r}-0.703 \\
(1.169)\end{array}$ & $\begin{array}{l}0.738 \\
(0.737)\end{array}$ & $\begin{array}{r}0.340 \\
(0.917)\end{array}$ & $\begin{array}{r}-0.886 \\
(1.166)\end{array}$ & $\begin{array}{l}0.907 \\
(0.699)\end{array}$ \\
\hline Period 4 & $\begin{array}{r}0.408 \\
(1.289)\end{array}$ & $\begin{array}{l}-0.607 \\
(1.472)\end{array}$ & $\begin{array}{c}1.273 \\
(0.977)\end{array}$ & $\begin{array}{l}0.237 \\
(1.288)\end{array}$ & $\begin{array}{l}-0.760 \\
(1.488)\end{array}$ & $\begin{array}{r}1.563^{*} \\
(0.930)\end{array}$ \\
\hline Period 5 & $\begin{array}{l}-0.121 \\
(1.755)\end{array}$ & $\begin{array}{l}-1.087 \\
(1.934)\end{array}$ & $\begin{array}{l}1.173 \\
(1.214)\end{array}$ & $\begin{array}{l}-0.563 \\
(1.760)\end{array}$ & $\begin{array}{l}-1.514 \\
(1.965)\end{array}$ & $\begin{array}{c}1.481 \\
(1.152)\end{array}$ \\
\hline Period 6 & $\begin{array}{c}1.247 \\
(2.058)\end{array}$ & $\begin{array}{c}0.264 \\
(2.221)\end{array}$ & $\begin{array}{l}2.755^{*} \\
(1.457)\end{array}$ & $\begin{array}{l}0.575 \\
(2.073)\end{array}$ & $\begin{array}{l}-0.421 \\
(2.254)\end{array}$ & $\begin{array}{l}2.926^{* *} \\
(1.396)\end{array}$ \\
\hline Period 7 & $\begin{array}{c}1.533 \\
(2.323)\end{array}$ & $\begin{array}{c}0.601 \\
(2.486)\end{array}$ & $\begin{array}{l}3.120^{*} \\
(1.668)\end{array}$ & $\begin{array}{c}0.778 \\
(2.369)\end{array}$ & $\begin{array}{l}-0.152 \\
(2.564)\end{array}$ & $\begin{array}{l}3.274^{*} \\
(1.657)\end{array}$ \\
\hline Number of observations & 474 & 479 & 477 & 467 & 472 & 470 \\
\hline Number of groups & 108 & 108 & 108 & 108 & 108 & 108 \\
\hline Number of instruments & 72 & 72 & 72 & 71 & 71 & 71 \\
\hline $\begin{array}{l}\text { Serial correlation test } \\
(p \text {-value }) \\
\text { Hansen test of } \\
\text { overidentifying } \\
\text { restrictions ( } p \text {-value) }\end{array}$ & 0.140 & 0.132 & 0.020 & 0.220 & 0.231 & 0.051 \\
\hline
\end{tabular}

$\mathrm{GDP}=$ gross domestic product, IMF = International Monetary Fund.

Notes: Robust standard errors in parentheses. ${ }^{*} p<0.1,{ }^{* *} p<0.05,{ }^{* * *} p<0.01$. Total capital flows, Lane and Milesi-Ferretti's measure of openness, liquid liabilities, initial real GDP per capita, inflation, and years of schooling are expressed in natural logarithms.

Source: Authors' estimates. 


\section{B. Evidence from Developing Countries}

To produce our results on developing countries, we interacted the financial openness and financial development indicators with a dummy variable that takes a value of 1 for a developing country (nonOrganization for Economic Co-operation Development [OECD] member) and added the interactions to our baseline specifications. We also added interactions between financial indicators and a developing Asia country dummy variable (that is, the Asian Development Bank's developing membercountries) to see whether the financial variables' effect on growth in Asia was any different.

Once we add the interaction dummies for developing countries, the coefficients for the financial development indicator generally turn from positive into negative (Table 2). In contrast, the coefficients on the interaction between financial development and developing country dummy are positive, significant, and robust across specifications. A similar trend is observed for the ratio of private credit to GDP but not for the ratio of stock market capitalization to GDP (Appendix tables A4.2 and A5.2). ${ }^{4}$ Positive effects of financial development on growth are particularly evident in developing countries, and the effects are even stronger in developing Asia. This finding reinforces the need to promote financial development to foster economic growth, particularly in light of the moderating trend of growth rate in the region since the global financial crisis.

The effect of financial openness on growth tends to be lower in developing countries than elsewhere, with some evidence of exceptions for developing Asian countries when financial development is represented by the ratio of private credit to GDP. Financial openness may bring about potential financial instability, which in turn may constrain economic growth. This interpretation is in line with the argument about the importance of a sound regulatory set-up for the finance sector (Jeanne et al. 2014). Because regulatory systems in developing countries are less mature than in developed countries, more financial openness tends to be associated with more volatility, which elevates the risks for investments, particularly in light of possible sudden reversals of capital flows. ${ }^{5}$

\section{Degree of Financial Development and Openness}

To assess the effect of financial development and openness on growth, we extend our baseline specification in two ways. The first is by adding an interaction of the financial openness indicator with a dummy of higher degree of financial development, defined to take a value of 1 if a country's degree of financial development is higher than the sample median. The second applies a similar approach to investigate the reverse concept, whether the effect of financial development on growth differs for countries with greater financial openness.

The effect of financial openness on growth tends to be lower in countries with higher levels of financial development (Table 3). The other specification also shows that the effect of financial development tends to be weaker in countries with higher degree of financial openness. These two complementary observations suggest that a combination of a high degree of financial development and financial openness could potentially limit growth potential, because they may expose countries to

4 For the ratio of stock market capitalization to GDP, the coefficients for the financial development indicator remains positive and the coefficients on the interaction with developing country dummy turn negative. The implications of this finding are the opposite of the implications of the other financial development indicators.

5 Countries need to carefully weigh the degree of effectiveness of their options for regulating the finance sector. RojasSuarez (2008) argues that regulations that incentivize financial institutions to avoid excessive risk-taking activities may work better in containing the risks of increased volatility in capital flows than regulations that directly control financial aggregates, such as liquidity expansion and credit growth. 
greater financial market volatility and higher risks for capital flow reversals. These findings reinforce the need for sound finance sector regulation that could reduce the sector's volatility, particularly when the size of domestic finance sector grows and its connection to the global financial system is enhanced.

Table 2: Results on Whether Effects in Developing Countries and Developing Asia Differ (Financial Development Indicator: Liquid Liabilities)

\begin{tabular}{|c|c|c|c|c|c|c|}
\hline \multirow[b]{2}{*}{ Variable } & \multicolumn{3}{|c|}{$\begin{array}{l}\text { Ilzetski, Reinhart, and Rogoff de facto } \\
\text { Indicator }\end{array}$} & \multicolumn{3}{|c|}{ IMF de jure Indicator } \\
\hline & $\begin{array}{l}\text { Total } \\
\text { Capital } \\
\text { Flows }\end{array}$ & $\begin{array}{l}\text { Lane and } \\
\text { Milesi- } \\
\text { Ferretti }\end{array}$ & $\begin{array}{l}\text { Chinn } \\
\text { and Ito }\end{array}$ & $\begin{array}{l}\text { Total } \\
\text { Capital } \\
\text { Flows }\end{array}$ & $\begin{array}{l}\text { Lane and } \\
\text { Milesi- } \\
\text { Ferretti }\end{array}$ & $\begin{array}{l}\text { Chinn } \\
\text { and Ito }\end{array}$ \\
\hline & $(1)$ & (2) & (3) & (4) & (5) & $(6)$ \\
\hline Financial openness & $\begin{array}{l}2.943^{* *} \\
(1.210)\end{array}$ & $\begin{array}{l}3.936^{* *} \\
(1.911)\end{array}$ & $\begin{array}{c}0.391 \\
(0.888)\end{array}$ & $\begin{array}{l}2.872^{* *} \\
(1.160)\end{array}$ & $\begin{array}{l}4.076^{* *} \\
(1.877)\end{array}$ & $\begin{array}{r}0.0467 \\
(0.820)\end{array}$ \\
\hline of GDP) & $\begin{array}{l}-6.858^{* *} \\
(2.981)\end{array}$ & $\begin{array}{l}-8.788^{* *} \\
(4.217)\end{array}$ & $\begin{array}{l}-5.113 \\
(3.318)\end{array}$ & $\begin{array}{l}-7.144^{* *} \\
(2.912)\end{array}$ & $\begin{array}{l}-9.242^{* *} \\
(4.372)\end{array}$ & $\begin{array}{l}-5.849^{*} \\
(2.993)\end{array}$ \\
\hline $\begin{array}{l}\text { Financial openness } x \\
\text { developing country }\end{array}$ & $\begin{array}{r}-2.166^{*} \\
(1.203)\end{array}$ & $\begin{array}{l}-3.948^{* *} \\
(1.780)\end{array}$ & $\begin{array}{l}-0.602 \\
(0.831)\end{array}$ & $\begin{array}{c}-2.029^{*} \\
(1.166)\end{array}$ & $\begin{array}{l}-4.054^{* *} \\
(1.758)\end{array}$ & $\begin{array}{l}-0.211 \\
(0.768)\end{array}$ \\
\hline $\begin{array}{l}\text { Liquid liabilities } x \\
\text { developing country }\end{array}$ & $\begin{array}{r}5.492^{*} \\
(2.815)\end{array}$ & $\begin{array}{r}7.564^{*} \\
(4.049)\end{array}$ & $\begin{array}{c}3.807 \\
(2.855)\end{array}$ & $\begin{array}{l}5.894^{* *} \\
(2.823)\end{array}$ & $\begin{array}{r}8.097^{*} \\
(4.224)\end{array}$ & $\begin{array}{r}4.792^{*} \\
(2.641)\end{array}$ \\
\hline $\begin{array}{l}\text { Financial openness x } \\
\text { developing Asia }\end{array}$ & $\begin{array}{l}0.872 \\
(1.044)\end{array}$ & $\begin{array}{c}1.901 \\
(1.671)\end{array}$ & $\begin{array}{c}0.570 \\
(0.495)\end{array}$ & $\begin{array}{l}0.817 \\
(1.043)\end{array}$ & $\begin{array}{l}2.127 \\
(1.745)\end{array}$ & $\begin{array}{c}0.660 \\
(0.489)\end{array}$ \\
\hline $\begin{array}{l}\text { Liquid liabillties } x \\
\text { developing Asia }\end{array}$ & $\begin{array}{l}5.033^{* * *} \\
(1.510) \\
\end{array}$ & $\begin{array}{l}4.536^{* * *} \\
(1.561)\end{array}$ & $\begin{array}{l}4.638^{* * *} \\
(1.143)\end{array}$ & $\begin{array}{l}5.148^{* * *} \\
(1.617)\end{array}$ & $\begin{array}{l}4.650^{* * *} \\
(1.696)\end{array}$ & $\begin{array}{l}4.605^{* * *} \\
(1.230)\end{array}$ \\
\hline Number of instruments & 76 & 76 & 76 & 75 & 75 & 75 \\
\hline $\begin{array}{l}\text { ( } p \text {-value) } \\
\text { Hansen test of } \\
\text { overidentifying restrictions } \\
(p \text {-value) }\end{array}$ & 0.129 & 0.238 & 0.044 & 0.148 & 0.161 & 0.074 \\
\hline
\end{tabular}

GDP = gross domestic product, IMF = International Monetary Fund.

Notes: Robust standard errors in parentheses. ${ }^{*} p<0.1$, ${ }^{* *} p<0.05,{ }^{* *} p<0.01$. Control variables, including period dummy variables indicated in table.1, are included in the estimation but not reported here. Total capital flows, Lane and Milesi-Ferretti's measure of openness, and liquid liabilities are expressed in natural logarithms.

Source: Authors' estimates. 
Table 3: Results on Whether Growth Effects Vary with Level of Financial Development and Openness (Financial Development Indicator: Liquid Liabilities)

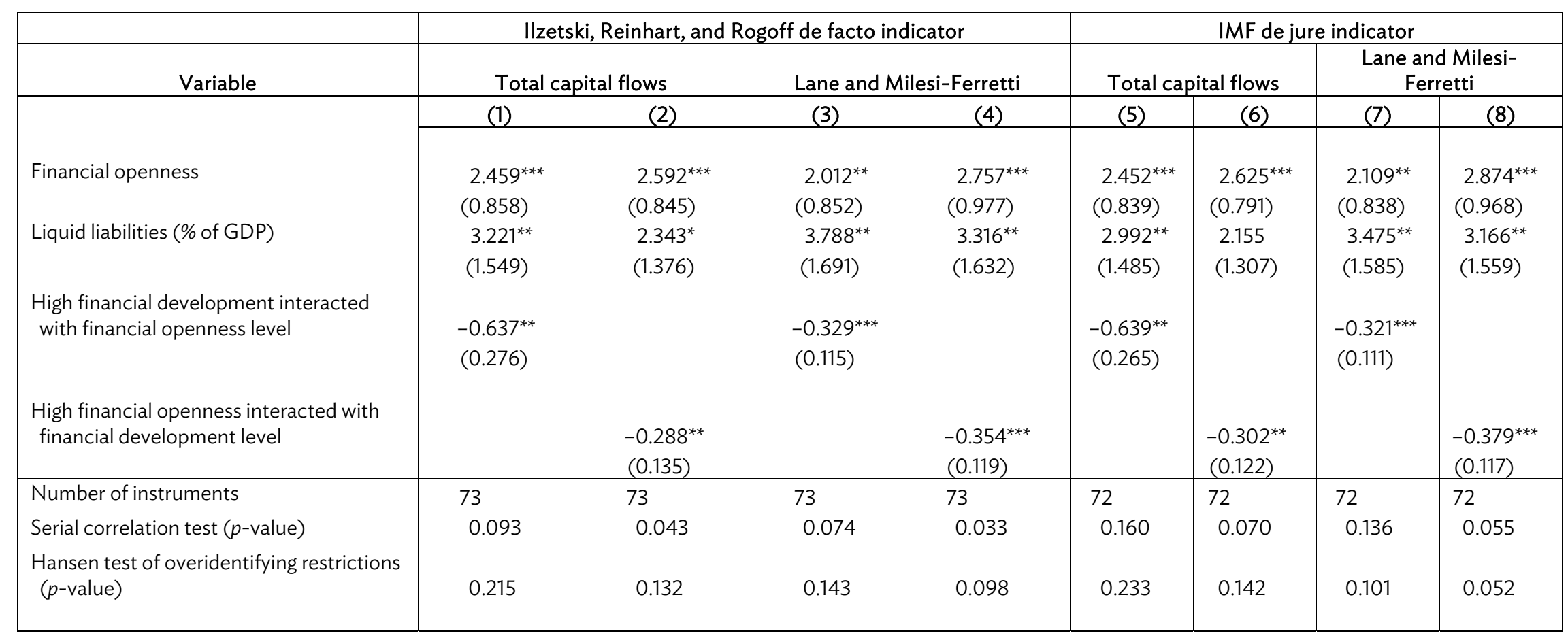

$\mathrm{GDP}=$ gross domestic product, IMF = International Monetary Fund.

Notes: Robust standard errors in parentheses. ${ }^{*} p<0.1,{ }^{* *} p<0.05,{ }^{* *} p<0.01$. Control variables, including period dummy variables indicated in table 1 , are included in the estimation but not reported here. Total capital flows, Lane and Milesi-Ferretti's measure of openness, and liquid liabilities are expressed in natural logarithms. Results for private credit and stock market capitalization as financial development indicators are shown in Appendix tables A4.3 and A5.3, respectively.

Source: Authors' estimates. 


\section{Effect of the Exchange Rate Regime}

To determine the effect of the exchange rate regime, we interacted dummy variables of different regimes with financial development variables. The results in Table 4 do not robustly indicate a statistically significant effect of managed and floating exchange rate regime on economic growth. This result is consistent with that of Ghosh et al. (1997), who find that growth varies only slightly across regimes.

Table 4 also shows some evidence that the effect of financial openness on growth is milder when coupled with a more flexible exchange rate regime, particularly under the IMF exchange rate regime definition and the Lane and Milesi-Ferretti definition of capital openness. This finding suggests that a more flexible exchange rate regime may reduce the effectiveness of financial openness in promoting economic growth. Table 4 also shows some evidence that financial development has a stronger effect on growth under a managed floating exchange rate regime. As long as it is credible, such a regime may offer more certainty for investment decisions, which could eventually enhance growth.

\section{E. Differences between FDI and Non-FDI}

FDI flows are often thought to increase growth more than other types of capital flows, for at least two reasons. First, FDI tends to be long term and hence less volatile than other types of capital flow. Second, FDI may have a stronger positive association with domestic investment relative to other types of capital flows and hence can be more effective in promoting economic growth (see, for example, Bosworth and Collins 1999, and Mody and Murshid 2005). This section revisits the issue by including $\mathrm{FDI}$ and non-FDI components of financial flow separately in the growth regressions.

Table 5 shows that FDI is positively associated with per capita economic growth, in terms of both total flows and stocks based on the Lane and Milesi-Ferretti definition. In contrast, the non-FDI components of capital flow appear to be positive and significant in terms of stocks based only on the Lane and Milesi-Ferretti definition. This finding suggests that in general, both FDI and non-FDI components of capital flow tend to be positively associated with economic growth but that evidence of positive effects of non-FDI flows on growth is weak.

We also investigate whether these effects are different in developing countries. The results show some positive effect of the FDI component on growth and weak evidence of the effect of nonFDI components (Table 6). Among developing countries, the effect of FDI on growth tends to be stronger in Asian countries. 
Table 4: Results on Whether Foreign Exchange Rate Regimes Matter (Financial Development Indicator: Liquid Liabilities)

\begin{tabular}{|c|c|c|c|c|c|c|}
\hline \multirow[b]{2}{*}{ Variable } & \multicolumn{3}{|c|}{$\begin{array}{l}\text { Ilzetski, Reinhart, and Rogoff de facto } \\
\text { indicator }\end{array}$} & \multicolumn{3}{|c|}{ IMF de jure indicator } \\
\hline & $\begin{array}{l}\text { Total capital } \\
\text { flows }\end{array}$ & $\begin{array}{l}\text { Lane and } \\
\text { Milesi- } \\
\text { Ferretti }\end{array}$ & $\begin{array}{l}\text { Chinn } \\
\text { and Ito }\end{array}$ & $\begin{array}{l}\text { Total capital } \\
\text { flows }\end{array}$ & $\begin{array}{l}\text { Lane and } \\
\text { Milesi- } \\
\text { Ferretti }\end{array}$ & $\begin{array}{l}\text { Chinn } \\
\text { and Ito }\end{array}$ \\
\hline & $(1)$ & $(2)$ & $(3)$ & $(4)$ & (5) & $(6)$ \\
\hline Financial openness & $\begin{array}{l}2.071^{*} \\
(1.213)\end{array}$ & $\begin{array}{l}2.205^{* *} \\
(0.983)\end{array}$ & $\begin{array}{l}-0.221 \\
(0.431)\end{array}$ & $\begin{array}{l}2.099^{* *} \\
(0.848)\end{array}$ & $\begin{array}{l}3.149^{* * *} \\
(0.951)\end{array}$ & $\begin{array}{l}-0.129 \\
(0.357)\end{array}$ \\
\hline Liquid liabilities (\% of GDP) & $\begin{array}{r}2.504 \\
(1.691)\end{array}$ & $\begin{array}{l}2.096 \\
(1.728)\end{array}$ & $\begin{array}{l}2.155 \\
(1.807)\end{array}$ & $\begin{array}{l}2.203^{*} \\
(1.303)\end{array}$ & $\begin{array}{l}1.859 \\
(1.438)\end{array}$ & $\begin{array}{l}2.183 \\
(1.433)\end{array}$ \\
\hline $\begin{array}{l}\text { Managed exchange rate } \\
\text { regime }\end{array}$ & $\begin{array}{c}1.789 \\
(2.818)\end{array}$ & $\begin{array}{l}3.413 \\
(3.470)\end{array}$ & $\begin{array}{c}0.015 \\
(2.972)\end{array}$ & $\begin{array}{l}-0.936 \\
(1.716)\end{array}$ & $\begin{array}{r}1.603 \\
(2.163)\end{array}$ & $\begin{array}{l}-1.188 \\
(1.659)\end{array}$ \\
\hline Flexible exchange rate regime & $\begin{array}{l}-1.250 \\
(4.947)\end{array}$ & $\begin{array}{l}1.917 \\
(6.505)\end{array}$ & $\begin{array}{l}-4.136 \\
(6.337)\end{array}$ & $\begin{array}{l}0.316 \\
(1.921)\end{array}$ & $\begin{array}{r}3.624 \\
(3.215)\end{array}$ & $\begin{array}{l}-1.404 \\
(2.018)\end{array}$ \\
\hline $\begin{array}{l}\text { Free falling/dual exchange rate } \\
\text { regime }\end{array}$ & $\begin{array}{l}7.521 \\
(5.219)\end{array}$ & $\begin{array}{c}0.243 \\
(6.179)\end{array}$ & $\begin{array}{c}1.242 \\
(4.536)\end{array}$ & & & \\
\hline $\begin{array}{l}\text { Financial openness } x \text { managed } \\
\text { exchange rate regime }\end{array}$ & $\begin{array}{l}-0.755 \\
(0.843)\end{array}$ & $\begin{array}{l}-0.875 \\
(0.574)\end{array}$ & $\begin{array}{l}-0.073 \\
(0.323)\end{array}$ & $\begin{array}{l}-0.254 \\
(0.457)\end{array}$ & $\begin{array}{l}-1.121^{* *} \\
(0.476)\end{array}$ & $\begin{array}{c}0.146 \\
(0.233)\end{array}$ \\
\hline $\begin{array}{l}\text { Financial openness } x \text { flexible } \\
\text { exchange rate regime }\end{array}$ & $\begin{array}{l}-0.632 \\
(1.044)\end{array}$ & $\begin{array}{l}-1.533 \\
(1.225)\end{array}$ & $\begin{array}{l}-0.082 \\
(0.637)\end{array}$ & $\begin{array}{l}-1.099^{*} \\
(0.618)\end{array}$ & $\begin{array}{l}-1.393^{*} \\
(0.719)\end{array}$ & $\begin{array}{l}-0.295 \\
(0.271)\end{array}$ \\
\hline $\begin{array}{l}\text { Financial openness } x \text { free } \\
\text { falling/dual exchange rate } \\
\text { regime }\end{array}$ & $\begin{array}{l}-2.189^{*} \\
(1.134)\end{array}$ & $\begin{array}{l}0.086 \\
(1.010)\end{array}$ & $\begin{array}{l}-0.500 \\
(0.550)\end{array}$ & & & \\
\hline $\begin{array}{l}\text { Liquid liabilities } x \text { managed } \\
\text { exchange rate regime }\end{array}$ & $\begin{array}{c}0.083 \\
(0.786)\end{array}$ & $\begin{array}{c}0.256 \\
(0.723)\end{array}$ & $\begin{array}{c}0.001 \\
(0.821)\end{array}$ & $\begin{array}{c}0.397 \\
(0.518)\end{array}$ & $\begin{array}{l}1.039^{* *} \\
(0.466)\end{array}$ & $\begin{array}{c}0.240 \\
(0.426)\end{array}$ \\
\hline $\begin{array}{l}\text { Liquid liabilities } x \text { flexible } \\
\text { exchange rate regime }\end{array}$ & $\begin{array}{l}0.784 \\
(1.273)\end{array}$ & $\begin{array}{c}1.496 \\
(1.398)\end{array}$ & $\begin{array}{c}1.134 \\
(1.778)\end{array}$ & $\begin{array}{c}0.464 \\
(0.522)\end{array}$ & $\begin{array}{c}0.686 \\
(0.608)\end{array}$ & $\begin{array}{c}0.231 \\
(0.546)\end{array}$ \\
\hline regime & $\begin{array}{c}-0.722 \\
(1.342)\end{array}$ & $\begin{array}{c}-0.122 \\
(1.247)\end{array}$ & $\begin{array}{c}-0.357 \\
(1.360)\end{array}$ & & & \\
\hline Number of instruments & 78 & 78 & 78 & 75 & 75 & 75 \\
\hline $\begin{array}{l}\text { Serial correlation test ( } p \text { - } \\
\text { value) } \\
\text { Hansen test of overidentifying } \\
\text { restrictions ( } p \text {-value) }\end{array}$ & $\begin{array}{l}0.191 \\
0.198\end{array}$ & 0.153 & 0.029 & 0.143 & $\begin{array}{l}0.158 \\
0.096\end{array}$ & $\begin{array}{l}0.028 \\
0.164\end{array}$ \\
\hline
\end{tabular}

GDP = gross domestic product, IMF = International Monetary Fund.

Notes: Robust standard errors in parentheses. ${ }^{*} p<0.1$, ${ }^{* *} p<0.05,{ }^{* * *} p<0.01$. Control variables, including period dummy variables indicated in table 1 , are included in the estimation but not reported here. Total capital flows, Lane and Milesi-Ferretti's measure of openness, and liquid liabilities are expressed in natural logarithms. Results for private credit and stock market capitalization as financial development indicators are shown in Appendix tables A4.4 and A5.4, respectively.

Source: Authors' estimates. 
Table 5: Baseline Results on Impact of FDI and Non-FDI on Growth

\begin{tabular}{|c|c|c|c|c|}
\hline \multirow[b]{2}{*}{ Variable } & \multicolumn{2}{|c|}{$\begin{array}{l}\text { Ilzetski, Reinhart, and Rogoff de facto } \\
\text { indicator }\end{array}$} & \multicolumn{2}{|c|}{ IMF de jure indicator } \\
\hline & Total flows & $\begin{array}{c}\text { Lane and Milesi- } \\
\text { Ferretti }\end{array}$ & Total flows & $\begin{array}{c}\text { Lane and } \\
\text { Milesi-Ferretti }\end{array}$ \\
\hline & $(1)$ & $(2)$ & (3) & $(4)$ \\
\hline Foreign direct investment (FDI) & $\begin{array}{l}0.920^{* *} \\
(0.378)\end{array}$ & $\begin{array}{l}1.288^{* *} \\
(0.585)\end{array}$ & $\begin{array}{l}0.968^{* * *} \\
(0.368)\end{array}$ & $\begin{array}{l}1.410^{* *} \\
(0.611)\end{array}$ \\
\hline Non-FDI & $\begin{array}{c}0.706 \\
(0.806)\end{array}$ & $\begin{array}{c}1.417^{* *} \\
(0.689)\end{array}$ & $\begin{array}{c}0.879 \\
(0.802)\end{array}$ & $\begin{array}{l}1.510^{* *} \\
(0.713)\end{array}$ \\
\hline Liquid liabilities (\% of GDP) & $\begin{array}{l}2.200 \\
(1.413)\end{array}$ & $\begin{array}{c}2.242 \\
(1.435)\end{array}$ & $\begin{array}{l}2.330^{*} \\
(1.345)\end{array}$ & $\begin{array}{l}2.551^{*} \\
(1.401)\end{array}$ \\
\hline Initial real per capita GDP & $\begin{array}{l}-11.49^{* * *} \\
(1.613)\end{array}$ & $\begin{array}{r}-13.10^{* * *} \\
(1.588)\end{array}$ & $\begin{array}{c}-11.50^{* * *} \\
(1.640)\end{array}$ & $\begin{array}{r}-13.31^{* * *} \\
(1.556)\end{array}$ \\
\hline Government spending (\% of GDP) & $\begin{array}{l}-2.784^{* *} \\
(1.102)\end{array}$ & $\begin{array}{l}-1.570 \\
(1.008)\end{array}$ & $\begin{array}{l}-3.246^{* * *} \\
(1.080)\end{array}$ & $\begin{array}{l}-1.987^{\star} \\
(1.020)\end{array}$ \\
\hline Inflation & $\begin{array}{l}-1.327^{* * *} \\
(0.447)\end{array}$ & $\begin{array}{l}-1.076^{* *} \\
(0.444)\end{array}$ & $\begin{array}{l}-1.509^{* * *} \\
(0.427)\end{array}$ & $\begin{array}{l}-1.167^{* * *} \\
(0.420)\end{array}$ \\
\hline Years of schooling & $\begin{array}{l}-1.164 \\
(2.933)\end{array}$ & $\begin{array}{c}1.223 \\
(3.068)\end{array}$ & $\begin{array}{l}-0.517 \\
(3.258)\end{array}$ & $\begin{array}{c}1.721 \\
(3.081)\end{array}$ \\
\hline Trade openness (\% of GDP) & $\begin{array}{r}1.463^{*} \\
(0.823)\end{array}$ & $\begin{array}{c}1.171 \\
(0.951)\end{array}$ & $\begin{array}{l}1.713^{* *} \\
(0.843)\end{array}$ & $\begin{array}{c}1.366 \\
(0.982)\end{array}$ \\
\hline Managed exchange rate regime & $\begin{array}{c}0.156 \\
(0.396)\end{array}$ & $\begin{array}{c}0.185 \\
(0.344)\end{array}$ & $\begin{array}{l}-0.182 \\
(0.331)\end{array}$ & $\begin{array}{l}-0.166 \\
(0.324)\end{array}$ \\
\hline Flexible exchange rate regime & $\begin{array}{c}0.422 \\
(0.727)\end{array}$ & $\begin{array}{c}0.381 \\
(0.752)\end{array}$ & $\begin{array}{l}-0.718^{*} \\
(0.425)\end{array}$ & $\begin{array}{l}-0.779^{* *} \\
(0.369)\end{array}$ \\
\hline Free falling/dual exchange rate regime & $\begin{array}{c}0.066 \\
(0.722)\end{array}$ & $\begin{array}{l}-0.027 \\
(0.708)\end{array}$ & & \\
\hline Period 2 & $\begin{array}{l}-0.211 \\
(0.538)\end{array}$ & $\begin{array}{l}-1.032 \\
(0.703)\end{array}$ & $\begin{array}{l}-0.278 \\
(0.564)\end{array}$ & $\begin{array}{l}-1.128 \\
(0.704)\end{array}$ \\
\hline Period 3 & $\begin{array}{r}0.405 \\
(0.941)\end{array}$ & $\begin{array}{l}-0.801 \\
(1.184)\end{array}$ & $\begin{array}{c}0.279 \\
(0.993)\end{array}$ & $\begin{array}{l}-0.920 \\
(1.171)\end{array}$ \\
\hline Period 4 & $\begin{array}{l}0.207 \\
(1.345)\end{array}$ & $\begin{array}{l}-0.834 \\
(1.509)\end{array}$ & $\begin{array}{l}0.044 \\
(1.434)\end{array}$ & $\begin{array}{c}-0.944 \\
(1.500)\end{array}$ \\
\hline Period 5 & $\begin{array}{l}-0.267 \\
(1.890)\end{array}$ & $\begin{array}{l}-1.499 \\
(1.990)\end{array}$ & $\begin{array}{l}-0.774 \\
(2.040)\end{array}$ & $\begin{array}{l}-1.877 \\
(1.965)\end{array}$ \\
\hline Period 6 & $\begin{array}{c}1.265 \\
(2.223)\end{array}$ & $\begin{array}{l}-0.240 \\
(2.266)\end{array}$ & $\begin{array}{c}0.509 \\
(2.377)\end{array}$ & $\begin{array}{l}-0.874 \\
(2.224)\end{array}$ \\
\hline Period 7 & $\begin{array}{c}1.423 \\
(2.450) \\
\end{array}$ & $\begin{array}{l}-0.010 \\
(2.499) \\
\end{array}$ & $\begin{array}{r}0.600 \\
(2.646) \\
\end{array}$ & $\begin{array}{l}-0.735 \\
(2.490) \\
\end{array}$ \\
\hline Number of observations & 455 & 477 & 448 & 470 \\
\hline Number of group & 108 & 108 & 108 & 108 \\
\hline Number of instruments & 84 & 84 & 83 & 83 \\
\hline $\begin{array}{l}\text { Serial correlation test ( } p \text {-value) } \\
\text { Hansen test of overidentifying restrictions } \\
(p \text {-value) }\end{array}$ & $\begin{array}{l}0.029 \\
0.169\end{array}$ & 0.179 & 0.055 & 0.372 \\
\hline
\end{tabular}

$\mathrm{FDI}=$ foreign direct investment, $\mathrm{GDP}=$ gross domestic product, IMF = International Monetary Fund.

Notes: Robust standard errors in parentheses. ${ }^{*} p<0.1,{ }^{* *} p<0.05,{ }^{* *} p<0.01$. Control variables, including period dummy variables indicated in table 1, are included in the estimation but not reported here. FDI, non-FDI, liquid liabilities, initial real GDP per capita, inflation, and years of schooling are expressed in natural logarithms.

Source: Authors' estimates. 
Table 6: Results on Whether Effects of FDI and Non-FDI on Growth Differ in Developing
Countries and Developing Asia

\begin{tabular}{|c|c|c|c|c|}
\hline \multirow[b]{2}{*}{ Variable } & \multicolumn{2}{|c|}{$\begin{array}{l}\text { Ilzetski, Reinhart, and Rogoff de } \\
\text { facto Indicator }\end{array}$} & \multicolumn{2}{|c|}{ IMF de jure Indicator } \\
\hline & Total Flows & $\begin{array}{c}\text { Lane and } \\
\text { Milesi-Ferretti }\end{array}$ & Total Flows & $\begin{array}{c}\text { Lane and } \\
\text { Milesi-Ferretti }\end{array}$ \\
\hline & (1) & $(2)$ & (3) & (4) \\
\hline Foreign direct investment (FDI) & $\begin{array}{l}2.344^{* *} \\
(1.127)\end{array}$ & $\begin{array}{l}0.698 \\
(1.664)\end{array}$ & $\begin{array}{l}2.006^{*} \\
(1.125)\end{array}$ & $\begin{array}{c}1.013 \\
(1.697)\end{array}$ \\
\hline Non-FDI & $\begin{array}{l}-1.852 \\
(1.752)\end{array}$ & $\begin{array}{r}2.740 \\
(2.431)\end{array}$ & $\begin{array}{l}-1.469 \\
(1.637)\end{array}$ & $\begin{array}{c}2.007 \\
(2.366)\end{array}$ \\
\hline FDI $x$ developing country & $\begin{array}{l}-1.910^{*} \\
(1.116)\end{array}$ & $\begin{array}{l}0.128 \\
(1.451)\end{array}$ & $\begin{array}{l}-1.553 \\
(1.103)\end{array}$ & $\begin{array}{l}-0.209 \\
(1.484)\end{array}$ \\
\hline Non-FDI $x$ developing country & $\begin{array}{l}1.887 \\
(1.767)\end{array}$ & $\begin{array}{l}-3.597 \\
(2.292)\end{array}$ & $\begin{array}{r}1.488 \\
(1.661)\end{array}$ & $\begin{array}{l}-2.868 \\
(2.246)\end{array}$ \\
\hline Liquid liabilities $x$ developing country & $\begin{array}{c}1.127 \\
(2.819)\end{array}$ & $\begin{array}{c}3.411 \\
(3.762)\end{array}$ & $\begin{array}{c}1.392 \\
(2.631)\end{array}$ & $\begin{array}{c}3.931 \\
(3.568)\end{array}$ \\
\hline FDI x developing Asia & $\begin{array}{l}0.901^{1 *} \\
(0.447)\end{array}$ & $\begin{array}{c}1.128 \\
(0.735)\end{array}$ & $\begin{array}{l}0.887^{*} \\
(0.461)\end{array}$ & $\begin{array}{r}1.352^{*} \\
(0.780)\end{array}$ \\
\hline Non-FDI x developing Asia & $\begin{array}{c}0.227 \\
(0.740)\end{array}$ & $\begin{array}{l}0.823 \\
(1.357)\end{array}$ & $\begin{array}{c}0.254 \\
(0.772)\end{array}$ & $\begin{array}{l}0.821 \\
(1.343)\end{array}$ \\
\hline Liquid liabilities $x$ developing Asia & $\begin{array}{l}3.561^{1 *} \\
(1.490)\end{array}$ & $\begin{array}{l}3.859^{* *} \\
(1.576)\end{array}$ & $\begin{array}{l}3.690^{* *} \\
(1.585)\end{array}$ & $\begin{array}{l}3.864^{* *} \\
(1.641)\end{array}$ \\
\hline Number of instruments & 78 & 78 & 77 & 77 \\
\hline $\begin{array}{l}\text { Serial correlation test ( } p \text {-value) } \\
\text { Hansen test of overidentifying } \\
\text { restrictions ( } p \text {-value) }\end{array}$ & $\begin{array}{l}0.155 \\
0.161 \\
\end{array}$ & $\begin{array}{l}0.223 \\
0.08\end{array}$ & 0.163 & 0.238 \\
\hline
\end{tabular}

$\mathrm{FDI}=$ foreign direct investment, $\mathrm{IMF}=$ International Monetary Fund.

Notes: Robust standard errors in parentheses. ${ }^{*} p<0.1$, ${ }^{* *} p<0.05,{ }^{* *} p<0.01$. Control variables, including period dummy variables indicated in table 1, are included in the estimation but not reported here. FDI and non-FDI, and liquid liabilities are expressed in natural logarithms.

Source: Authors' estimates.

\section{CONCLUDING OBSERVATIONS}

This paper examines the empirical relationship between financial development and economic growth. The relationship has been studied extensively in the past. Now is a particularly good time to revisit it for a number of reasons. First, the global financial crisis has provoked widespread hostility toward the financial industry and widespread skepticism about its benefits for growth. Although such concerns are less relevant for developing countries, where financial systems are generally much less developed, they nevertheless provide compelling grounds for taking another look at the effect of financial development on growth. Second, because their financial systems are underdeveloped, building up a sounder and more efficient financial system can increase growth in developing countries. Growth considerations are always important for developing countries, but they have gained significance in light of the global slowdown since the financial crisis. In the case of developing Asia, a gap between backward financial systems and dynamic real economies strengthens the case for financial development. 
A large body of empirical literature examines the effects of financial development and financial openness on growth. Much of the evidence on financial development finds a positive and significant effect; the evidence on the effect of financial openness is much more mixed.

Our empirical analysis is rooted in and follows the literature but extends it in a number of incremental ways. First, we update the sample period to 2011, to include a number of postglobal crisis years. Second, we introduce several interaction variables, in order to investigate the impact of country characteristics on the finance-growth nexus. In particular, we are interested in whether the effect of financial development on growth differs in advanced versus developing countries. Third, we introduce additional variables, including the exchange rate regime, that might influence the finance-growth nexus. Fourth, we use generalized method of moments estimation to tackle potential simultaneity problems (the fact that causality from economic growth to both financial development and financial openness may run in both directions). For example, rapid growth and expansion of the middle class fuels demand for financial services, and a country's strong growth performance and prospects attract foreign capital inflows.

Most of our findings are consistent with earlier studies. Above all, we find that it is overall financial development, rather than the composition of the financial system, that matters for growth. The shares of both the banking sector and stock market activities relative to GDP are positively associated with economic growth. It is thus not the development of banks, stock markets, or specific components of the financial system but rather the development of the financial system as a whole that contributes to growth.

An important additional finding is that the positive effect of financial development on growth is stronger in developing countries than in advanced economies. The effect is especially pronounced in developing Asia. These findings are consistent with our earlier conjecture that postglobal financial crisis concerns about excessive finance and a potentially harmful impact of finance on growth are more relevant for advanced economies than for developing countries. They also reinforce our hunch that developing Asia stands to reap large gains from correcting the imbalance between its financial backwardness and real-economy dynamism. The overriding policy implication of our evidence is that financial development can serve as an engine of growth for developing countries, especially in Asia. For middle- and upper-middle-income Asian countries with mature banking sectors, a top priority is to broaden and deepen capital markets, especially bond markets. For lower-income Asian countries, a higher priority is to develop and strengthen the banking sector.

Our evidence on the relationship between financial openness and economic growth is mixed, in line with the inconclusive evidence of previous studies. We find that actual financial openness has a positive and significant effect on economic growth but de jure measures do not. This finding implies that a commitment to open up the domestic financial system to foreign capital inflows does not benefit growth until it stimulates actual inflows. In addition, we find that the effect of financial openness on growth tends to be weaker in developing countries. One possible interpretation is that the financial systems of the advanced economies are better able to allocate foreign capital inflows to productive uses. The Asian crisis underlined the devastating consequences of the failure of developing country financial systems to efficiently allocate foreign capital. But somewhat paradoxically, we also find that the effect of financial openness on growth tends to be weaker in financially more developed countries. This finding may reflect the fact that our measure of financial development is a quantitative indicator that captures the relative size of the finance sector and that the potential for capital inflows to destabilize the real economy is greater in a larger finance sector. 
Our analysis fails to yield robust evidence about the direct effect of the exchange rate regime on economic growth. It does, however, find some evidence that a more flexible exchange rate regime can have a greater indirect effect on growth through both financial openness and financial development.

Although our empirical analysis reconfirms the positive and significant impact of financial development on growth, it is far from perfect. Future research can extend and strengthen the analytical framework in various ways. Perhaps the single biggest shortcoming of our analysis is the measures of financial development. Although our indexes of financial development are standard indexes widely used in earlier studies in the literature, they measure the relative size of the finance sector rather than the soundness and efficiency of the finance sector. It would be more illuminating to directly examine the relationship between a measure of the quality of finance and growth. Future research could devise a conceptually sound measure of quality of finance that is empirically testable (that is, for which data are available).

Finally, our analysis examines financial development and growth. Financial stability also has implications for growth. Financial instability in general and financial crisis in particular can adversely affect growth and even cause economic crises, as evident in the impact of the global and Asian financial crises. Future research could focus on this issue. 


\section{APPENDIX TABLE A1: RECLASSIFICATION OF CODES}

\begin{tabular}{lll}
\hline Coarse Classification & Reclassification \\
\hline 1 & No separate legal tender & 1 Fixed \\
1 & Preannounced peg or currency board arrangement & 1 Fixed \\
1 & Preannounced horizontal band that is narrower than or equal to $+/-2 \%$ & 1 Fixed \\
1 & De facto peg & 1 Fixed \\
2 & Preannounced crawling peg & 2 Managed \\
2 & Preannounced crawling band that is narrower than or equal to $+/-2 \%$ & 2 Managed \\
2 & De facto crawling peg & 2 Managed \\
2 & De facto crawling band that is narrower than or equal to $+/-2 \%$ & 2 Managed \\
3 & Preannounced crawling band that is wider than or equal to $+/-2 \%$ & 2 Managed \\
3 & De facto crawling band that is narrower than or equal to $+/-5 \%$ & 2 Managed \\
3 & Moving band that is narrower than or equal to $+/-2 \%$ (that is, allows for both & 2 Managed \\
3 & Managed floating & 2 Managed \\
4 & Freely floating & 3 Flexible \\
5 & Freely falling & 4 Freely falling/dual market \\
6 & Dual market in which parallel market data is missing & 4 Freely falling/dual market \\
\hline
\end{tabular}

Source: Authors' compilation based on Ilzetski, Reinhart, and Rogoff (2011). 
APPENDIX TABLE A2: CORRELATION COEFFICIENTS OF VARIABLES

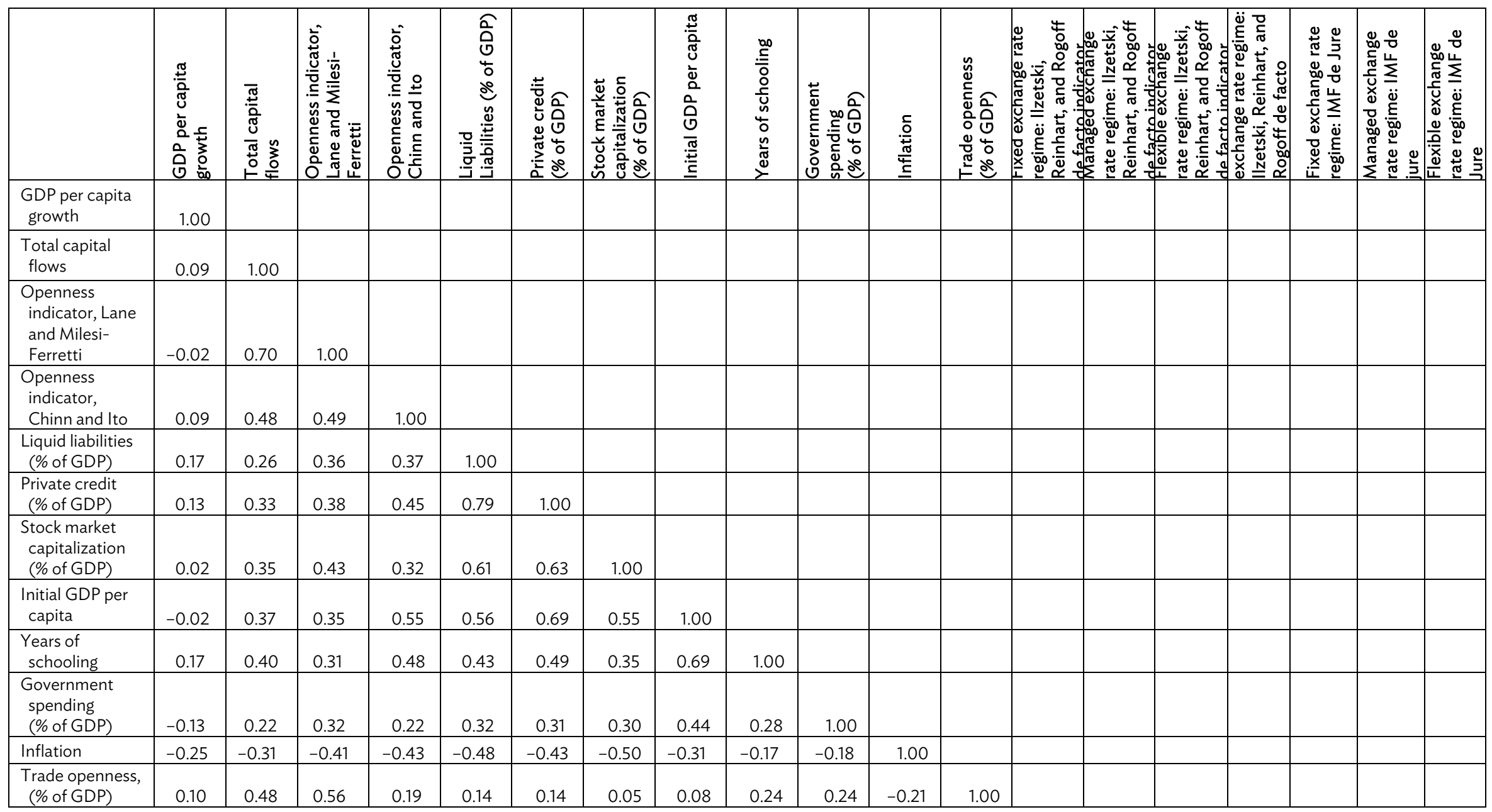


Appendix 2 continued

\begin{tabular}{|c|c|c|c|c|c|c|c|c|c|c|c|c|c|c|c|c|c|c|c|}
\hline & 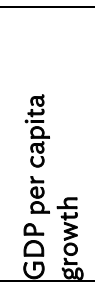 & 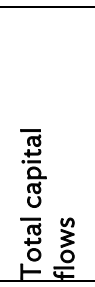 & 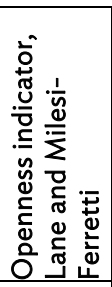 & 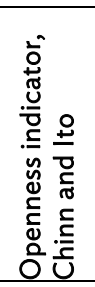 & 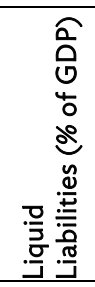 & 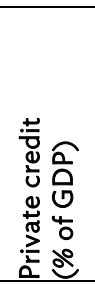 & 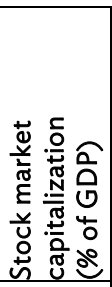 & 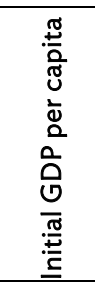 & 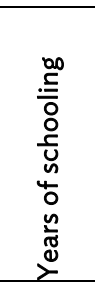 & 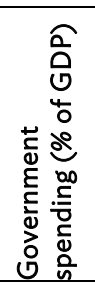 & 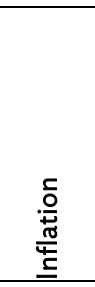 & 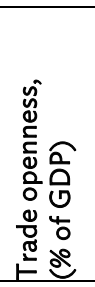 & 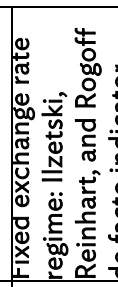 & 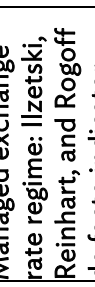 & 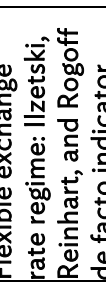 & 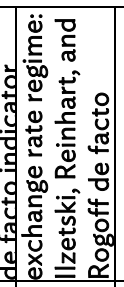 & 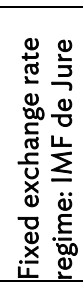 & 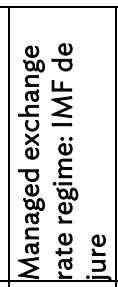 & 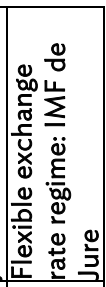 \\
\hline $\begin{array}{l}\text { Fixed exchange } \\
\text { rate regime: } \\
\text { Ilzetski, } \\
\text { Reinhart, and } \\
\text { Rogoff de facto } \\
\text { indicator } \\
\end{array}$ & -0.08 & 0.26 & 0.25 & 0.07 & -0.01 & 0.07 & 0.18 & -0.02 & -0.17 & 0.11 & -0.29 & 0.26 & 1.00 & & & & & & \\
\hline $\begin{array}{l}\text { Managed } \\
\text { exchange rate } \\
\text { regime: Ilzetski, } \\
\text { Reinhart, and } \\
\text { Rogoff de facto } \\
\text { indicator }\end{array}$ & 0.21 & -0.20 & -0.16 & -0.02 & 0.11 & 0.03 & -0.14 & -0.01 & 0.09 & -0.10 & -0.04 & -0.05 & -0.74 & 1.00 & & & & & \\
\hline $\begin{array}{l}\text { Flexible } \\
\text { exchange rate } \\
\text { regime: Ilzetski, } \\
\text { Reinhart, and } \\
\text { Rogoff de facto } \\
\text { indicator }\end{array}$ & -0.02 & 0.02 & 0.04 & 0.17 & 0.16 & 0.13 & 0.23 & 0.16 & 0.13 & 0.05 & -0.12 & -0.22 & -0.16 & -0.24 & 1.00 & & & & \\
\hline $\begin{array}{l}\text { Free falling/ dual } \\
\text { exchange rate } \\
\text { regime: Ilzetski, } \\
\text { Reinhart, and } \\
\text { Rogoff de facto } \\
\text { indicator }\end{array}$ & -0.22 & -0.10 & -0.16 & -0.19 & -0.30 & -0.27 & -0.25 & -0.08 & 0.02 & -0.05 & 0.61 & -0.16 & -0.22 & -0.34 & -0.07 & 1.00 & & & \\
\hline $\begin{array}{l}\text { Fixed exchange } \\
\text { rate regime: } \\
\text { IMF de jure }\end{array}$ & -0.18 & -0.01 & 0.02 & -0.24 & -0.18 & -0.17 & -0.01 & -0.20 & -0.30 & 0.10 & 0.02 & 0.14 & 0.40 & -0.26 & -0.13 & $\begin{array}{l}- \\
0.10\end{array}$ & 1.00 & & \\
\hline $\begin{array}{l}\text { Managed } \\
\text { exchange rate } \\
\text { regime: IMF de } \\
\text { jure }\end{array}$ & 0.19 & -0.02 & -0.04 & 0.05 & 0.11 & 0.11 & -0.03 & 0.10 & 0.12 & -0.06 & -0.01 & -0.02 & -0.18 & 0.21 & -0.10 & 0.00 & -0.63 & 1.00 & \\
\hline $\begin{array}{l}\text { Flexible } \\
\text { exchange rate } \\
\text { regime: IMF de } \\
\text { Jure }\end{array}$ & -0.01 & 0.04 & 0.02 & 0.23 & 0.09 & 0.07 & 0.04 & 0.13 & 0.23 & -0.06 & -0.01 & -0.15 & -0.27 & 0.08 & 0.27 & 0.10 & -0.47 & -0.39 & 1.00 \\
\hline
\end{tabular}

$\mathrm{GDP}=$ gross domestic product, IMF = International Monetary Fund.

Source: Authors' estimates. 


\section{APPENDIX TABLE A3: LIST OF ECONOMIES IN THE SAMPLE}

\begin{tabular}{|c|c|c|c|c|c|}
\hline & Developing Asia & 15 & Congo, Republic of & 52 & Moldova \\
\hline 1 & Armenia (ARM) & 16 & Costa Rica & 53 & Morocco \\
\hline 2 & Bangladesh (BAN) & 17 & Côte d'Ivoire & 54 & Mozambique \\
\hline 3 & Cambodia (CAM) & 18 & Croatia & 55 & Namibia \\
\hline 4 & $\begin{array}{l}\text { People's Republic of China } \\
\text { (PRC) }\end{array}$ & 19 & Cyprus & 56 & Netherlands \\
\hline 5 & Fiji (FIJ) & 20 & Czech Republic & 57 & New Zealand \\
\hline 6 & India (IND) & 21 & Denmark & 58 & Nicaragua \\
\hline 7 & Indonesia (INO) & 22 & Dominican Republic & 59 & Niger \\
\hline 8 & Kazakhstan (KAZ) & 23 & Ecuador & 60 & Norway \\
\hline 9 & Republic of Korea (KOR) & 24 & Egypt, Arab Republic of & 61 & Panama \\
\hline 10 & Kyrgyz Republic (KGZ) & 25 & El Salvador & 62 & Paraguay \\
\hline 11 & Malaysia (MAL) & 26 & Finland & 63 & Peru \\
\hline 12 & Mongolia (MON) & 27 & France & 64 & Poland \\
\hline 13 & Nepal (NEP) & 28 & Gabon & 65 & Portugal \\
\hline 14 & Pakistan (PAK) & 29 & Gambia, The & 66 & Russian Federation \\
\hline 15 & Philippines (PHI) & 30 & Germany & 67 & Saudi Arabia \\
\hline 16 & Singapore (SIN) & 31 & Ghana & 68 & Senegal \\
\hline 17 & Sri Lanka (SRI) & 32 & Greece & 69 & Slovenia \\
\hline 18 & Tajikistan (TAJ) & 33 & Guatemala & 70 & South Africa \\
\hline 19 & Thailand (THA) & 34 & Guyana & 71 & Spain \\
\hline \multirow[t]{3}{*}{20} & Viet Nam (VIE) & 35 & Honduras & 72 & Sudan \\
\hline & & 36 & Hungary & 73 & Swaziland \\
\hline & Other economies (88) & 37 & Iran, Islamic Republic of & 74 & Sweden \\
\hline 1 & Albania & 38 & Ireland & 75 & Switzerland \\
\hline 2 & Australia & 39 & Israel & 76 & Syrian Arab Republic \\
\hline 3 & Austria & 40 & Italy & 77 & Tanzania \\
\hline 4 & Bahrain & 41 & Japan & 78 & Togo \\
\hline 5 & Belgium & 42 & Jordan & 79 & Trinidad and Tobago \\
\hline 6 & Benin & 43 & Kenya & 80 & Tunisia \\
\hline 7 & Bolivia & 44 & Kuwait & 81 & Turkey \\
\hline 8 & Botswana & 45 & Latvia & 82 & Uganda \\
\hline 9 & Brazil & 46 & Lesotho & 83 & Ukraine \\
\hline 10 & Bulgaria & 47 & Liberia & 84 & United Kingdom \\
\hline 11 & Burundi & 48 & Lithuania & 85 & United States \\
\hline 12 & Cameroon & 49 & Malawi & 86 & Uruguay \\
\hline 13 & Canada & 50 & Mali & 87 & Zambia \\
\hline 14 & Colombia & 51 & Mexico & 88 & Zimbabwe \\
\hline
\end{tabular}

Source: Authors. 


\section{APPENDIX TABLE A4: REGRESSION RESULTS FOR PRIVATE CREDIT AS FINANCIAL DEVELOPMENT INDICATOR}

Table A4.1: Baseline Results (Financial Development Indicator: Private Credit)

\begin{tabular}{|c|c|c|c|c|c|c|}
\hline \multirow[b]{2}{*}{ Variable } & \multicolumn{3}{|c|}{$\begin{array}{l}\text { Ilzetski, Reinhart, and Rogoff de facto } \\
\text { Indicator }\end{array}$} & \multicolumn{3}{|c|}{ IMF de jure Indicator } \\
\hline & $\begin{array}{l}\text { Total Capital } \\
\text { Flows }\end{array}$ & $\begin{array}{l}\text { Lane and } \\
\text { Milesi- } \\
\text { Ferretti }\end{array}$ & $\begin{array}{l}\text { Chinn } \\
\text { and Ito }\end{array}$ & Total Flows & $\begin{array}{l}\text { Lane and } \\
\text { Milesi- } \\
\text { Ferretti }\end{array}$ & $\begin{array}{l}\text { Chinn } \\
\text { and Ito }\end{array}$ \\
\hline & $(1)$ & $(2)$ & (3) & (4) & (5) & $(6)$ \\
\hline Financial openness & $\begin{array}{l}1.780^{* *} \\
(0.727)\end{array}$ & $\begin{array}{l}2.146^{* *} \\
(0.942)\end{array}$ & $\begin{array}{l}-0.221 \\
(0.330)\end{array}$ & $\begin{array}{l}1.823^{* *} \\
(0.760)\end{array}$ & $\begin{array}{l}2.293^{* *} \\
(0.951)\end{array}$ & $\begin{array}{l}-0.187 \\
(0.310)\end{array}$ \\
\hline Private credit (\%of GDP) & $\begin{array}{r}1.509^{*} \\
(0.821)\end{array}$ & $\begin{array}{r}1.507^{*} \\
(0.774)\end{array}$ & $\begin{array}{l}1.608^{* *} \\
(0.715)\end{array}$ & $\begin{array}{r}1.525^{*} \\
(0.837)\end{array}$ & $\begin{array}{l}1.748^{* *} \\
(0.832)\end{array}$ & $\begin{array}{l}1.745^{* *} \\
(0.729)\end{array}$ \\
\hline Initial real per capita GDP & $\begin{array}{r}-12.36^{* * *} \\
(1.823)\end{array}$ & $\begin{array}{r}-12.90^{* * *} \\
(1.582)\end{array}$ & $\begin{array}{c}-11.79^{* * *} \\
(1.642)\end{array}$ & $\begin{array}{c}-12.20^{* * *} \\
(1.811)\end{array}$ & $\begin{array}{r}-13.02^{* * *} \\
(1.608)\end{array}$ & $\begin{array}{c}-11.87^{* * *} \\
(1.631)\end{array}$ \\
\hline $\begin{array}{l}\text { Government spending } \\
\text { (\% of GDP) }\end{array}$ & $\begin{array}{l}-2.608^{* *} \\
(0.999)\end{array}$ & $\begin{array}{l}-1.700^{*} \\
(0.992)\end{array}$ & $\begin{array}{l}-1.840^{*} \\
(0.944)\end{array}$ & $\begin{array}{l}-2.875^{* * *} \\
(0.959)\end{array}$ & $\begin{array}{l}-2.073^{* *} \\
(0.968)\end{array}$ & $\begin{array}{l}-2.162^{* *} \\
(0.911)\end{array}$ \\
\hline Inflation & $\begin{array}{l}-1.696^{* * *} \\
(0.506)\end{array}$ & $\begin{array}{l}-1.592^{* * *} \\
(0.437)\end{array}$ & $\begin{array}{l}-1.747^{* * *} \\
(0.445)\end{array}$ & $\begin{array}{l}-1.931^{* * *} \\
(0.437)\end{array}$ & $\begin{array}{l}-1.760^{* * *} \\
(0.362)\end{array}$ & $\begin{array}{l}-1.785^{* * *} \\
(0.369)\end{array}$ \\
\hline Years of schooling & $\begin{array}{l}0.165 \\
(2.859)\end{array}$ & $\begin{array}{c}2.118 \\
(3.396)\end{array}$ & $\begin{array}{l}-0.854 \\
(2.234)\end{array}$ & $\begin{array}{c}1.589 \\
(2.950)\end{array}$ & $\begin{array}{c}3.062 \\
(3.486)\end{array}$ & $\begin{array}{l}-0.081 \\
(2.294)\end{array}$ \\
\hline Trade openness (\% of GDP) & $\begin{array}{r}1.510^{*} \\
(0.859)\end{array}$ & $\begin{array}{r}1.646^{*} \\
(0.960)\end{array}$ & $\begin{array}{l}2.655^{* * *} \\
(0.850)\end{array}$ & $\begin{array}{l}1.834^{* *} \\
(0.875)\end{array}$ & $\begin{array}{r}1.717^{*} \\
(0.973)\end{array}$ & $\begin{array}{l}2.809^{* * *} \\
(0.855)\end{array}$ \\
\hline Managed exchange rate regime & $\begin{array}{r}0.486^{*} \\
(0.289)\end{array}$ & $\begin{array}{c}0.234 \\
(0.325)\end{array}$ & $\begin{array}{l}0.125 \\
(0.320)\end{array}$ & $\begin{array}{l}-0.0324 \\
(0.334)\end{array}$ & $\begin{array}{l}-0.124 \\
(0.301)\end{array}$ & $\begin{array}{l}-0.180 \\
(0.299)\end{array}$ \\
\hline Flexible exchange rate regime & $\begin{array}{l}-0.278 \\
(0.587)\end{array}$ & $\begin{array}{l}-0.042 \\
(0.694)\end{array}$ & $\begin{array}{l}-0.074 \\
(0.591)\end{array}$ & $\begin{array}{l}-0.688^{*} \\
(0.371)\end{array}$ & $\begin{array}{l}-0.693^{*} \\
(0.351)\end{array}$ & $\begin{array}{l}-0.658^{*} \\
(0.363)\end{array}$ \\
\hline $\begin{array}{l}\text { Free falling/dual exchange rate } \\
\text { regime }\end{array}$ & $\begin{array}{c}0.375 \\
(0.859)\end{array}$ & $\begin{array}{c}0.050 \\
(0.874)\end{array}$ & $\begin{array}{c}0.176 \\
(0.853)\end{array}$ & & & \\
\hline Period 2 & $\begin{array}{l}-0.241 \\
(0.562)\end{array}$ & $\begin{array}{l}-1.202 \\
(0.833)\end{array}$ & $\begin{array}{l}-0.309 \\
(0.475)\end{array}$ & $\begin{array}{l}-0.448 \\
(0.551)\end{array}$ & $\begin{array}{l}-1.380^{*} \\
(0.828)\end{array}$ & $\begin{array}{l}-0.392 \\
(0.451)\end{array}$ \\
\hline Period 3 & $\begin{array}{c}0.346 \\
(0.972)\end{array}$ & $\begin{array}{l}-0.935 \\
(1.400)\end{array}$ & $\begin{array}{c}0.618 \\
(0.796)\end{array}$ & $\begin{array}{l}-0.010 \\
(0.941)\end{array}$ & $\begin{array}{l}-1.203 \\
(1.386)\end{array}$ & $\begin{array}{c}0.495 \\
(0.756)\end{array}$ \\
\hline Period 4 & $\begin{array}{l}0.272 \\
(1.401)\end{array}$ & $\begin{array}{c}-0.955 \\
(1.774)\end{array}$ & $\begin{array}{l}1.117 \\
(1.057)\end{array}$ & $\begin{array}{c}-0.208 \\
(1.370)\end{array}$ & $\begin{array}{l}-1.253 \\
(1.758)\end{array}$ & $\begin{array}{l}0.986 \\
(1.010)\end{array}$ \\
\hline Period 5 & $\begin{array}{l}-0.305 \\
(2.008)\end{array}$ & $\begin{array}{l}-1.675 \\
(2.425)\end{array}$ & $\begin{array}{l}0.942 \\
(1.401)\end{array}$ & $\begin{array}{l}-1.192 \\
(1.971)\end{array}$ & $\begin{array}{l}-2.264 \\
(2.399)\end{array}$ & $\begin{array}{l}0.629 \\
(1.336)\end{array}$ \\
\hline Period 6 & $\begin{array}{r}1.093 \\
(2.318)\end{array}$ & $\begin{array}{l}-0.330 \\
(2.772)\end{array}$ & $\begin{array}{l}2.560 \\
(1.642)\end{array}$ & $\begin{array}{l}-0.073 \\
(2.293)\end{array}$ & $\begin{array}{l}-1.191 \\
(2.757)\end{array}$ & $\begin{array}{l}2.027 \\
(1.587)\end{array}$ \\
\hline Period 7 & $\begin{array}{c}1.515 \\
(2.563) \\
\end{array}$ & $\begin{array}{c}0.091 \\
(3.053) \\
\end{array}$ & $\begin{array}{r}3.060 \\
(1.850) \\
\end{array}$ & $\begin{array}{c}0.217 \\
(2.564) \\
\end{array}$ & $\begin{array}{c}-0.876 \\
(3.083) \\
\end{array}$ & $\begin{array}{c}2.435 \\
(1.843) \\
\end{array}$ \\
\hline Number of observations & 476 & 481 & 479 & 469 & 474 & 472 \\
\hline Number of group & 108 & 108 & 108 & 108 & 108 & 108 \\
\hline Number of instruments & 72 & 72 & 72 & 71 & 71 & 71 \\
\hline $\begin{array}{l}\text { Serial correlation test ( } p \text {-value) } \\
\text { Hansen test of overidentifying } \\
\text { restrictions ( } p \text {-value) }\end{array}$ & $\begin{array}{l}0.270 \\
0.077\end{array}$ & $\begin{array}{l}0.243 \\
0.112\end{array}$ & $\begin{array}{l}0.050 \\
0.116\end{array}$ & 0.340 & $\begin{array}{l}0.370 \\
0.078\end{array}$ & $\begin{array}{l}0.092 \\
0.170\end{array}$ \\
\hline
\end{tabular}

$\mathrm{GDP}=$ gross domestic product, $\mathrm{IMF}=$ International Monetary Fund.

Notes: Robust standard errors in parentheses. ${ }^{*} p<0.1,{ }^{* *} p<0.05,{ }^{* * *} p<0.01$. Total capital flows, Lane and Milesi-Ferretti's measure of openness, private credit, initial real GDP per capita, inflation, and years of schooling are expressed in natural logarithms.

Source: Authors' estimates. 
Table A4.2: Results on Whether Effects in Developing Countries and Developing Asia Differ (Financial Development Indicator: Private Credit)

\begin{tabular}{|c|c|c|c|c|c|c|}
\hline \multirow[b]{2}{*}{ Variable } & \multicolumn{3}{|c|}{$\begin{array}{l}\text { Ilzetski, Reinhart, and Rogoff de facto } \\
\text { Indicator }\end{array}$} & \multicolumn{3}{|c|}{ IMF de jure Indicator } \\
\hline & $\begin{array}{l}\text { Total } \\
\text { Capital } \\
\text { Flows }\end{array}$ & $\begin{array}{c}\text { Lane and } \\
\text { Milesi- } \\
\text { Ferretti }\end{array}$ & $\begin{array}{l}\text { Chinn } \\
\text { and Ito }\end{array}$ & $\begin{array}{l}\text { Total Capital } \\
\text { Flows }\end{array}$ & $\begin{array}{c}\text { Lane and } \\
\text { Milesi- } \\
\text { Ferretti }\end{array}$ & $\begin{array}{l}\text { Chinn } \\
\text { and Ito }\end{array}$ \\
\hline & $(1)$ & $(2)$ & (3) & $(4)$ & $(5)$ & $(6)$ \\
\hline Financial openness & $\begin{array}{l}2.522^{* *} \\
(1.226)\end{array}$ & $\begin{array}{c}3.358 \\
(2.276)\end{array}$ & $\begin{array}{c}0.591 \\
(0.767)\end{array}$ & $\begin{array}{l}2.810^{* *} \\
(1.288)\end{array}$ & $\begin{array}{c}3.350 \\
(2.278)\end{array}$ & $\begin{array}{c}0.561 \\
(0.801)\end{array}$ \\
\hline Private credit (\% of GDP) & $\begin{array}{l}-8.069^{* * *} \\
(2.845)\end{array}$ & $\begin{array}{l}-7.565^{* *} \\
(3.058)\end{array}$ & $\begin{array}{l}-3.653 \\
(2.509)\end{array}$ & $\begin{array}{l}-8.208^{* * *} \\
(2.814)\end{array}$ & $\begin{array}{l}-7.687^{* *} \\
(3.074)\end{array}$ & $\begin{array}{l}-3.573 \\
(2.473)\end{array}$ \\
\hline $\begin{array}{l}\text { Financial openness } x \text { developing } \\
\text { country }\end{array}$ & $\begin{array}{c}-2.141^{*} \\
(1.212)\end{array}$ & $\begin{array}{l}-3.955^{*} \\
(2.076)\end{array}$ & $\begin{array}{l}-0.874 \\
(0.761)\end{array}$ & $\begin{array}{c}-2.301^{*} \\
(1.294)\end{array}$ & $\begin{array}{l}-3.927^{*} \\
(2.113)\end{array}$ & $\begin{array}{l}-0.833 \\
(0.814)\end{array}$ \\
\hline $\begin{array}{l}\text { Private credit } x \text { developing } \\
\text { country }\end{array}$ & $\begin{array}{l}8.243^{* * *} \\
(2.704)\end{array}$ & $\begin{array}{l}8.135^{* * *} \\
(3.054)\end{array}$ & $\begin{array}{l}3.959^{*} \\
(2.314)\end{array}$ & $\begin{array}{l}8.326^{* * *} \\
(2.674)\end{array}$ & $\begin{array}{l}8.242^{* * *} \\
(3.073)\end{array}$ & $\begin{array}{c}3.891^{*} \\
(2.293)\end{array}$ \\
\hline $\begin{array}{l}\text { Financial openness x developing } \\
\text { Asia }\end{array}$ & $\begin{array}{l}2.409^{* *} \\
(1.118)\end{array}$ & $\begin{array}{l}3.571^{* *} \\
(1.504)\end{array}$ & $\begin{array}{c}0.995^{*} \\
(0.565)\end{array}$ & $\begin{array}{l}2.358^{* *} \\
(1.139)\end{array}$ & $\begin{array}{l}3.745^{* *} \\
(1.563)\end{array}$ & $\begin{array}{c}1.065^{*} \\
(0.572)\end{array}$ \\
\hline Private credit $x$ developing Asia & $\begin{array}{l}0.970 \\
(1.056)\end{array}$ & $\begin{array}{c}0.867 \\
(0.897) \\
\end{array}$ & $\begin{array}{c}1.763^{* *} \\
(0.826)\end{array}$ & $\begin{array}{c}1.065 \\
(1.056) \\
\end{array}$ & $\begin{array}{c}0.863 \\
(0.914) \\
\end{array}$ & $\begin{array}{l}1.760^{* *} \\
(0.815) \\
\end{array}$ \\
\hline Number of instruments & 76 & 76 & 76 & 75 & 75 & 75 \\
\hline Serial correlation test ( $p$-value) & 0.139 & 0.124 & 0.062 & 0.175 & 0.169 & 0.100 \\
\hline $\begin{array}{l}\text { Hansen test of overidentifying } \\
\text { restrictions ( } p \text {-value) }\end{array}$ & 0.248 & 0.080 & 0.081 & 0.295 & 0.070 & 0.102 \\
\hline
\end{tabular}

$\mathrm{GDP}=$ gross domestic product, $\mathrm{IMF}=$ International Monetary Fund.

Notes: Robust standard errors in parentheses. ${ }^{*} p<0.1,{ }^{* *} p<0.05$, ${ }^{* *} p<0.01$. Control variables, including period dummy variables indicated in table 1 , are included in the estimation but not reported here. Total capital flows, Lane and Milesi-Ferretti's measure of openness, and private credit are expressed in natural logarithms.

Source: Authors' estimates. 
Table A4.3: Results on Whether Growth Effects Vary with Level of Financial Development and Openness (Financial Development Indicator: Private Credit)

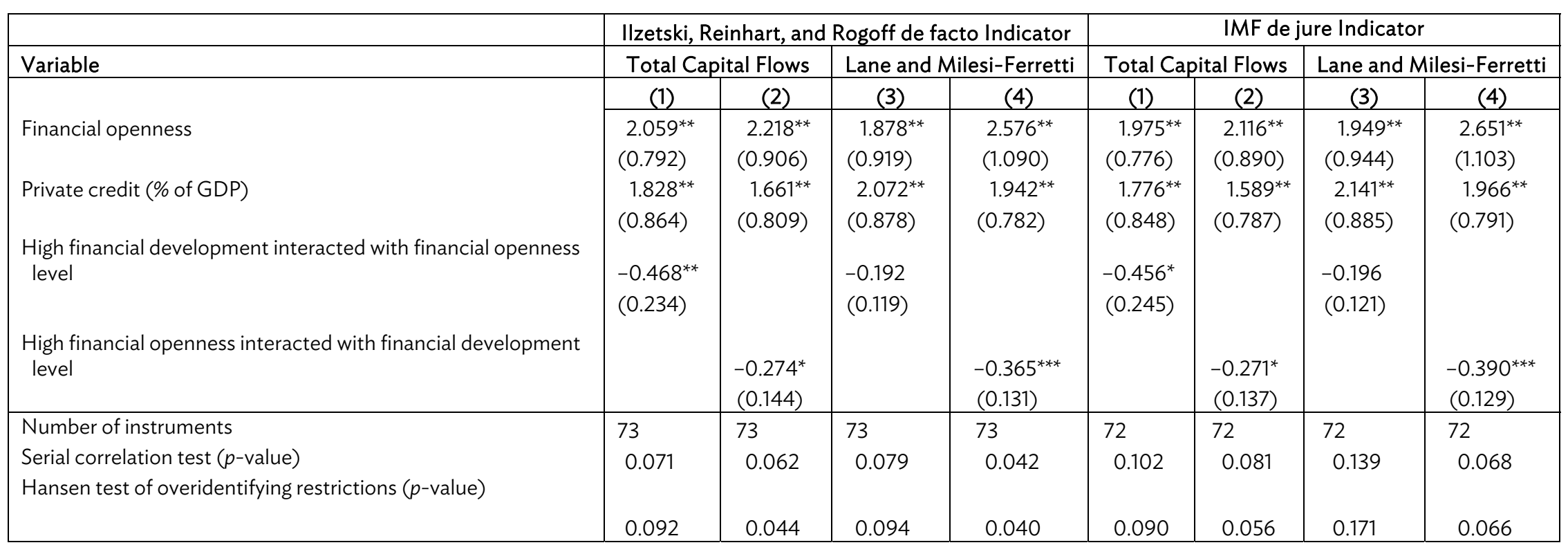

GDP = gross domestic product, IMF = International Monetary Fund.

Note: Robust standard errors in parentheses. ${ }^{*} p<0.1,{ }^{* *} p<0.05,{ }^{* * *} p<0.01$. Control variables, including period dummy variables indicated in table 1 , are included in the estimation but not reported here. Total capital flows, Lane and Milesi-Ferretti's measure of openness, and private credit are expressed in natural logarithms.

Source: Authors' estimates. 


\section{Table A4.4: Results on Whether Foreign Exchange Rate Regimes Matter (Financial Development Indicator: Private Credit)}

\begin{tabular}{|c|c|c|c|c|c|c|}
\hline \multirow[b]{2}{*}{ Variable } & \multicolumn{3}{|c|}{$\begin{array}{l}\text { Ilzetski, Reinhart, and Rogoff } \\
\text { de facto }\end{array}$} & \multicolumn{3}{|c|}{ IMF de jure } \\
\hline & $\begin{array}{l}\text { Total } \\
\text { Capital } \\
\text { Flows }\end{array}$ & $\begin{array}{l}\text { Lane and } \\
\text { Milesi- } \\
\text { Ferretti }\end{array}$ & $\begin{array}{l}\text { Chinn } \\
\text { and Ito }\end{array}$ & $\begin{array}{l}\text { Total } \\
\text { Capital } \\
\text { Flows } \\
\end{array}$ & $\begin{array}{l}\text { Lane and } \\
\text { Milesi- } \\
\text { Ferretti }\end{array}$ & $\begin{array}{l}\text { Chinn } \\
\text { and Ito }\end{array}$ \\
\hline & $(1)$ & (2) & (3) & (4) & (5) & $(6)$ \\
\hline Financial openness & $\begin{array}{c}1.743 \\
(1.359)\end{array}$ & $\begin{array}{l}2.411^{* *} \\
(1.191)\end{array}$ & $\begin{array}{l}-0.158 \\
(0.519)\end{array}$ & $\begin{array}{r}1.622^{*} \\
(0.906)\end{array}$ & $\begin{array}{l}3.142^{* * *} \\
(1.071)\end{array}$ & $\begin{array}{l}-0.0576 \\
(0.399)\end{array}$ \\
\hline Private credit (\% of GDP) & $\begin{array}{l}0.356 \\
(0.878)\end{array}$ & $\begin{array}{c}0.163 \\
(0.984)\end{array}$ & $\begin{array}{l}-0.073 \\
(0.875)\end{array}$ & $\begin{array}{r}1.050 \\
(0.901)\end{array}$ & $\begin{array}{l}0.663 \\
(1.023)\end{array}$ & $\begin{array}{l}0.753 \\
(0.824)\end{array}$ \\
\hline $\begin{array}{l}\text { Managed exchange rate } \\
\text { regime }\end{array}$ & $\begin{array}{l}0.378 \\
(2.236)\end{array}$ & $\begin{array}{c}3.768 \\
(2.967)\end{array}$ & $\begin{array}{l}-2.583 \\
(2.783)\end{array}$ & $\begin{array}{l}-1.085 \\
(1.376)\end{array}$ & $\begin{array}{l}1.711 \\
(1.764)\end{array}$ & $\begin{array}{l}-3.113^{* *} \\
(1.491)\end{array}$ \\
\hline $\begin{array}{l}\text { Flexible exchange rate } \\
\text { regime }\end{array}$ & $\begin{array}{l}-1.482 \\
(3.153)\end{array}$ & $\begin{array}{c}3.704 \\
(5.370)\end{array}$ & $\begin{array}{l}-5.782 \\
(4.027)\end{array}$ & $\begin{array}{l}-0.077 \\
(1.486)\end{array}$ & $\begin{array}{c}4.248 \\
(2.728)\end{array}$ & $\begin{array}{r}-2.937^{*} \\
(1.578)\end{array}$ \\
\hline $\begin{array}{l}\text { Free falling/dual exchange } \\
\text { rate regime }\end{array}$ & $\begin{array}{r}0.669 \\
(3.198)\end{array}$ & $\begin{array}{l}-4.275 \\
(5.300)\end{array}$ & $\begin{array}{l}-5.383 \\
(3.696)\end{array}$ & & & \\
\hline $\begin{array}{l}\text { Financial openness } x \\
\text { managed exchange rate } \\
\text { regime }\end{array}$ & $\begin{array}{l}-0.709 \\
(0.978)\end{array}$ & $\begin{array}{l}-1.307^{*} \\
(0.702)\end{array}$ & $\begin{array}{l}-0.293 \\
(0.434)\end{array}$ & $\begin{array}{l}-0.132 \\
(0.496)\end{array}$ & $\begin{array}{l}-1.215^{* *} \\
(0.474)\end{array}$ & $\begin{array}{l}-0.043 \\
(0.259)\end{array}$ \\
\hline $\begin{array}{l}\text { Financial openness } x \\
\text { flexible exchange rate } \\
\text { regime }\end{array}$ & $\begin{array}{l}-0.503 \\
(0.968)\end{array}$ & $\begin{array}{l}-1.705 \\
(1.349)\end{array}$ & $\begin{array}{l}-0.666 \\
(0.829)\end{array}$ & $\begin{array}{l}-1.072^{*} \\
(0.633)\end{array}$ & $\begin{array}{l}-1.679^{* *} \\
(0.693)\end{array}$ & $\begin{array}{l}-0.517^{*} \\
(0.292)\end{array}$ \\
\hline $\begin{array}{l}\text { Financial openness } x \text { free } \\
\text { falling/dual exchange } \\
\text { rate regime }\end{array}$ & $\begin{array}{l}-1.838 \\
(1.138)\end{array}$ & $\begin{array}{r}-0.058 \\
(1.175)\end{array}$ & $\begin{array}{l}-0.482 \\
(0.571)\end{array}$ & & & \\
\hline $\begin{array}{l}\text { Private credit } x \text { managed } \\
\text { exchange rate regime }\end{array}$ & $\begin{array}{c}0.464 \\
(0.834)\end{array}$ & $\begin{array}{c}0.743 \\
(0.742)\end{array}$ & $\begin{array}{c}0.748 \\
(0.791)\end{array}$ & $\begin{array}{c}0.404 \\
(0.525)\end{array}$ & $\begin{array}{l}1.182^{* *} \\
(0.464)\end{array}$ & $\begin{array}{l}0.814^{* *} \\
(0.401)\end{array}$ \\
\hline $\begin{array}{l}\text { Private credit } x \text { flexible } \\
\text { exchange rate regime }\end{array}$ & $\begin{array}{l}0.817 \\
(0.930)\end{array}$ & $\begin{array}{c}1.371 \\
(0.961)\end{array}$ & $\begin{array}{l}1.775 \\
(1.265)\end{array}$ & $\begin{array}{c}0.587 \\
(0.535)\end{array}$ & $\begin{array}{r}0.933^{*} \\
(0.503)\end{array}$ & $\begin{array}{c}0.714 \\
(0.463)\end{array}$ \\
\hline $\begin{array}{l}\text { Private credit } x \text { free } \\
\text { falling/dual exchange } \\
\text { rate regime }\end{array}$ & $\begin{array}{l}1.240 \\
(1.275)\end{array}$ & $\begin{array}{c}1.613 \\
(1.233)\end{array}$ & $\begin{array}{c}1.779 \\
(1.314)\end{array}$ & & & \\
\hline Number of instruments & 78 & 78 & 78 & 75 & 75 & 75 \\
\hline $\begin{array}{l}\text { Serial correlation test ( } p \text { - } \\
\text { value) } \\
\text { Hansen test of } \\
\text { overidentifying } \\
\text { restrictions ( } p \text {-value) }\end{array}$ & 0.402 & 0.415 & 0.104 & 0.199 & 0.232 & 0.061 \\
\hline
\end{tabular}

$\mathrm{GDP}=$ gross domestic product, $\mathrm{IMF}=$ International Monetary Fund.

Notes: Robust standard errors in parentheses. ${ }^{*} p<0.1,{ }^{* *} p<0.05,{ }^{* * *} p<0.01$. Control variables, including period dummy variables indicated in table 1, are included in the estimation but not reported here. Total capital flows, Lane and Milesi-Ferretti's measure of openness, and private credit are expressed in natural logarithms.

Source: Authors' estimates. 


\section{APPENDIX TABLE A5: REGRESSION RESULTS FOR STOCK MARKET CAPITALIZATION AS FINANCIAL DEVELOPMENT INDICATOR}

\section{Table A5.1: Baseline Results (Financial Development Indicator: Stock Market Capitalization)}

\begin{tabular}{|c|c|c|c|c|c|c|}
\hline \multirow{3}{*}{ Variable } & \multicolumn{3}{|c|}{$\begin{array}{l}\text { Ilzetski, Reinhart, and Rogoff de facto } \\
\text { Indicator }\end{array}$} & \multicolumn{3}{|c|}{ IMF de jure Indicator } \\
\hline & $\begin{array}{l}\text { Total } \\
\text { Capital } \\
\text { Flows }\end{array}$ & $\begin{array}{l}\text { Lane and } \\
\text { Milesi- } \\
\text { Ferretti }\end{array}$ & $\begin{array}{l}\text { Chinn } \\
\text { and Ito }\end{array}$ & $\begin{array}{l}\text { Total } \\
\text { Capital } \\
\text { Flows }\end{array}$ & $\begin{array}{l}\text { Lane and } \\
\text { Milesi- } \\
\text { Ferretti }\end{array}$ & $\begin{array}{l}\text { Chinn } \\
\text { and Ito }\end{array}$ \\
\hline & $(1)$ & $(2)$ & (3) & (4) & (5) & (6) \\
\hline Financial openness & $\begin{array}{l}0.675 \\
(0.852)\end{array}$ & $\begin{array}{l}2.021^{*} \\
(1.157)\end{array}$ & $\begin{array}{l}-0.972^{* *} \\
(0.437)\end{array}$ & $\begin{array}{c}0.857 \\
(0.825)\end{array}$ & $\begin{array}{l}2.224^{*} \\
(1.194)\end{array}$ & $\begin{array}{l}-1.015^{* *} \\
(0.425)\end{array}$ \\
\hline $\begin{array}{l}\text { Stock market capitalization } \\
\text { (\% of GDP) }\end{array}$ & $\begin{array}{l}2.799^{* * *} \\
(0.522)\end{array}$ & $\begin{array}{l}2.337^{* * *} \\
(0.413)\end{array}$ & $\begin{array}{l}3.151^{* * *} \\
(0.535)\end{array}$ & $\begin{array}{l}2.746^{* * *} \\
(0.524)\end{array}$ & $\begin{array}{l}2.331^{* * *} \\
(0.385)\end{array}$ & $\begin{array}{l}3.113^{* * *} \\
(0.537)\end{array}$ \\
\hline Initial real per capita GDP & $\begin{array}{l}-12.70^{* * *} \\
(1.641)\end{array}$ & $\begin{array}{c}-12.46^{* * *} \\
(1.441)\end{array}$ & $\begin{array}{r}-12.31^{* * *} \\
(1.509)\end{array}$ & $\begin{array}{c}-12.54^{* * *} \\
(1.673)\end{array}$ & $\begin{array}{c}-12.28^{* * *} \\
(1.426)\end{array}$ & $\begin{array}{r}-12.18^{* * *} \\
(1.506)\end{array}$ \\
\hline $\begin{array}{l}\text { Government spending } \\
\text { (\% of GDP) }\end{array}$ & $\begin{array}{l}-1.027 \\
(1.394)\end{array}$ & $\begin{array}{l}-1.298 \\
(1.295)\end{array}$ & $\begin{array}{l}-0.616 \\
(1.415)\end{array}$ & $\begin{array}{l}-1.426 \\
(1.444)\end{array}$ & $\begin{array}{l}-1.627 \\
(1.333)\end{array}$ & $\begin{array}{l}-0.659 \\
(1.400)\end{array}$ \\
\hline Inflation & $\begin{array}{l}-0.278 \\
(0.434)\end{array}$ & $\begin{array}{l}-0.655^{*} \\
(0.387)\end{array}$ & $\begin{array}{l}-0.881 \\
(0.591)\end{array}$ & $\begin{array}{l}-0.386 \\
(0.434)\end{array}$ & $\begin{array}{l}-0.799^{* *} \\
(0.396)\end{array}$ & $\begin{array}{l}-0.813 \\
(0.566)\end{array}$ \\
\hline Years of schooling & $\begin{array}{l}-2.461 \\
(3.997)\end{array}$ & $\begin{array}{c}3.162 \\
(4.706)\end{array}$ & $\begin{array}{l}-5.159 \\
(3.764)\end{array}$ & $\begin{array}{l}-1.516 \\
(4.105)\end{array}$ & $\begin{array}{c}4.140 \\
(4.966)\end{array}$ & $\begin{array}{l}-4.656 \\
(3.853)\end{array}$ \\
\hline Trade openness (\% of GDP) & $\begin{array}{l}-0.864 \\
(1.395)\end{array}$ & $\begin{array}{l}-1.174 \\
(1.434)\end{array}$ & $\begin{array}{l}-0.379 \\
(1.333)\end{array}$ & $\begin{array}{l}-0.890 \\
(1.428)\end{array}$ & $\begin{array}{l}-1.202 \\
(1.408)\end{array}$ & $\begin{array}{r}-0.478 \\
(1.359)\end{array}$ \\
\hline Managed exchange rate regime & $\begin{array}{c}0.427 \\
(0.422)\end{array}$ & $\begin{array}{c}0.479 \\
(0.404)\end{array}$ & $\begin{array}{c}0.311 \\
(0.425)\end{array}$ & $\begin{array}{l}0.316 \\
(0.399)\end{array}$ & $\begin{array}{l}0.415 \\
(0.396)\end{array}$ & $\begin{array}{c}0.481 \\
(0.379)\end{array}$ \\
\hline Flexible exchange rate regime & $\begin{array}{l}-0.860 \\
(0.931)\end{array}$ & $\begin{array}{l}-0.487 \\
(0.985)\end{array}$ & $\begin{array}{l}0.010 \\
(0.897)\end{array}$ & $\begin{array}{l}0.285 \\
(0.460)\end{array}$ & $\begin{array}{l}0.323 \\
(0.428)\end{array}$ & $\begin{array}{l}0.516 \\
(0.477)\end{array}$ \\
\hline $\begin{array}{l}\text { Free falling/dual exchange rate } \\
\text { regime }\end{array}$ & $\begin{array}{c}0.304 \\
(0.966)\end{array}$ & $\begin{array}{c}0.307 \\
(0.886)\end{array}$ & $\begin{array}{l}0.721 \\
(1.020)\end{array}$ & & & \\
\hline Period 3 & $\begin{array}{l}-0.521 \\
(0.696)\end{array}$ & $\begin{array}{l}-0.658 \\
(1.474)\end{array}$ & $\begin{array}{l}-2.927^{* * *} \\
(1.042)\end{array}$ & $\begin{array}{l}-1.103 \\
(1.763)\end{array}$ & $\begin{array}{r}1.009 \\
(2.105)\end{array}$ & \\
\hline Period 4 & $\begin{array}{l}-0.421 \\
(1.160)\end{array}$ & $\begin{array}{l}-1.402 \\
(0.875)\end{array}$ & $\begin{array}{l}-2.676^{* * *} \\
(0.649)\end{array}$ & $\begin{array}{l}-1.865 \\
(1.226)\end{array}$ & $\begin{array}{l}-0.157 \\
(1.537)\end{array}$ & $\begin{array}{l}-0.037 \\
(0.493)\end{array}$ \\
\hline Period 5 & $\begin{array}{l}1.345 \\
(1.520)\end{array}$ & $\begin{array}{l}-0.114 \\
(0.472)\end{array}$ & $\begin{array}{l}-0.645^{*} \\
(0.375)\end{array}$ & $\begin{array}{l}-2.012^{* * *} \\
(0.736)\end{array}$ & $\begin{array}{l}-1.221 \\
(0.872)\end{array}$ & $\begin{array}{c}0.123 \\
(0.866)\end{array}$ \\
\hline Period 6 & $\begin{array}{c}1.753 \\
(1.795)\end{array}$ & & & $\begin{array}{l}-0.314 \\
(0.407)\end{array}$ & $\begin{array}{l}-0.014 \\
(0.471)\end{array}$ & $\begin{array}{l}2.165^{*} \\
(1.154)\end{array}$ \\
\hline Period 7 & & $\begin{array}{l}0.254 \\
(1.972)\end{array}$ & $\begin{array}{l}-2.973^{* *} \\
(1.329)\end{array}$ & & & $\begin{array}{l}2.737^{* *} \\
(1.344)\end{array}$ \\
\hline Number of observations & 271 & 273 & 272 & 266 & 268 & 267 \\
\hline Number of group & 86 & 86 & 86 & 86 & 86 & 86 \\
\hline Number of instruments & 60 & 60 & 60 & 59 & 59 & 59 \\
\hline $\begin{array}{l}\text { Serial correlation test ( } p \text {-value) } \\
\text { Hansen test of overidentifying } \\
\text { restrictions ( } p \text {-value) }\end{array}$ & 0.384 & 0.444 & 0.366 & 0.401 & 0.531 & 0.339 \\
\hline
\end{tabular}

$\mathrm{GDP}=$ gross domestic product, $\mathrm{IMF}=$ International Monetary Fund.

Notes: Robust standard errors in parentheses. ${ }^{*} p<0.1,{ }^{* *} p<0.05,{ }^{* *} p<0.01$. Total capital flows, Lane and Milesi-Ferretti's measure of openness, stock market capitalization, initial real GDP per capita, inflation, and years of schooling are expressed in natural logarithms.

Source: Authors' estimates. 
Table A5.2: Results on Whether Effects in Developing Countries and Developing Asia Differ (Financial Development Indicator: Stock Market Capitalization)

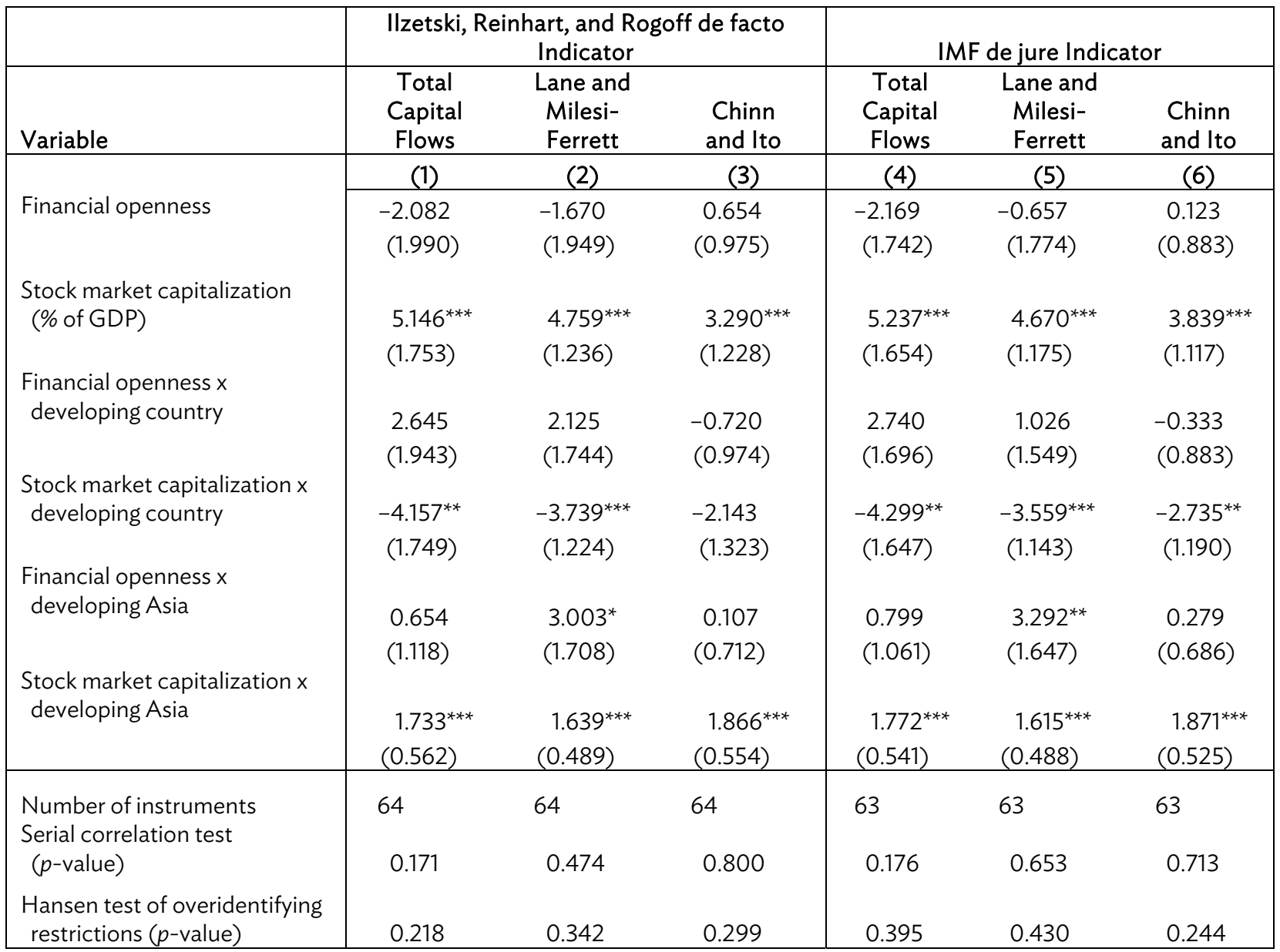

$\mathrm{GDP}=$ gross domestic product, IMF = International Monetary Fund.

Notes: Robust standard errors in parentheses. ${ }^{*} p<0.1,{ }^{* *} p<0.05,{ }^{* * *} p<0.01$. Control variables, including period dummy variables indicated in table 1, are included in the estimation but not reported here. Total capital flows, Lane and Milesi-Ferretti's measure of openness, and stock market capitalization are expressed in natural logarithms.

Source: Authors' estimates. 
Table A5.3: Results on Whether Growth Effects Vary with Level of Financial Development and Openness (Financial Development Indicator: Stock Market Capitalization)

\begin{tabular}{|c|c|c|c|c|c|c|c|c|}
\hline \multirow{4}{*}{$\begin{array}{l}\text { Variable } \\
\text { Financial openness }\end{array}$} & \multicolumn{4}{|c|}{ Ilzetski, Reinhart, and Rogoff de facto Indicator } & \multicolumn{4}{|c|}{ IMF de jure Indicator } \\
\hline & \multicolumn{2}{|c|}{ Total Capital Flows } & \multicolumn{2}{|c|}{ Lane and Milesi-Ferretti } & \multicolumn{2}{|c|}{ Total Capital Flows } & \multicolumn{2}{|c|}{ Lane and Milesi-Ferrett } \\
\hline & $(1)$ & (2) & (3) & (4) & $(1)$ & $(2)$ & (3) & (4) \\
\hline & $\begin{array}{c}1.205 \\
(0.946)\end{array}$ & $\begin{array}{l}0.921 \\
(1.063)\end{array}$ & $\begin{array}{r}1.693 \\
(1.181)\end{array}$ & $\begin{array}{l}2.579^{* *} \\
(1.293)\end{array}$ & $\begin{array}{c}1.260 \\
(0.963)\end{array}$ & $\begin{array}{c}0.733 \\
(0.963)\end{array}$ & $\begin{array}{c}1.998^{*} \\
(1.187)\end{array}$ & $\begin{array}{l}2.824^{* *} \\
(1.289)\end{array}$ \\
\hline Stock market capitalization ( $\%$ of GDP) & $\begin{array}{l}2.784^{* * *} \\
(0.574)\end{array}$ & $\begin{array}{l}2.879^{* * *} \\
(0.522)\end{array}$ & $\begin{array}{l}2.485^{* * *} \\
(0.472)\end{array}$ & $\begin{array}{l}2.694^{* * *} \\
(0.431)\end{array}$ & $\begin{array}{l}2.763^{* * *} \\
(0.571)\end{array}$ & $\begin{array}{l}2.812^{* * *} \\
(0.526)\end{array}$ & $\begin{array}{l}2.440^{* * *} \\
(0.438)\end{array}$ & $\begin{array}{l}2.621^{* * *} \\
(0.384)\end{array}$ \\
\hline $\begin{array}{l}\text { High financial development interacted with } \\
\text { financial openness level } \\
\text { High financial openness interacted with } \\
\text { financial development level }\end{array}$ & $\begin{array}{l}-0.437^{* *} \\
(0.210)\end{array}$ & $\begin{array}{c}-0.357 \\
(0.217)\end{array}$ & $\begin{array}{c}-0.221^{* *} \\
(0.087)\end{array}$ & $\begin{array}{l}-0.439^{* * *} \\
(0.151)\end{array}$ & $\begin{array}{l}-0.473^{* *} \\
(0.211)\end{array}$ & $\begin{array}{l}-0.323 \\
(0.200)\end{array}$ & $\begin{array}{c}-0.235^{* * *} \\
(0.0832)\end{array}$ & $\begin{array}{l}-0.455^{* * *} \\
(0.147)\end{array}$ \\
\hline $\begin{array}{l}\text { Number of instruments } \\
\text { Serial correlation test ( } p \text {-value) } \\
\text { Hansen test of overidentifying restrictions } \\
\text { ( } p \text {-value) }\end{array}$ & $\begin{array}{l}61 \\
0.069 \\
0.067\end{array}$ & $\begin{array}{l}61 \\
0.294 \\
0.068\end{array}$ & $\begin{array}{l}61 \\
0.184 \\
0.098\end{array}$ & $\begin{array}{l}61 \\
0.234\end{array}$ & $\begin{array}{l}60 \\
0.086 \\
0.071\end{array}$ & $\begin{array}{l}60 \\
0.337 \\
0.065\end{array}$ & $\begin{array}{l}60 \\
0.252 \\
0.126\end{array}$ & $\begin{array}{l}60 \\
0.279 \\
0.084\end{array}$ \\
\hline
\end{tabular}

GDP = gross domestic product, IMF = International Monetary Fund.

Notes: Robust standard errors in parentheses. ${ }^{*} p<0.1,{ }^{* *} p<0.05,{ }^{* *} p<0.01$. Control variables, including period dummy variables indicated in table 1 , are included in the estimation but not reported here. Total capital flows, Lane and Milesi-Ferretti's measure of openness, and stock market capitalization are expressed in natural logarithms.

Source: Authors' estimates. 


\section{Table A5.4: Results on Whether Foreign Exchange Rate Regimes Matter (Financial Development Indicator: Stock Market Capitalization)}

\begin{tabular}{|c|c|c|c|c|c|c|}
\hline & Ilzetski, F & $\begin{array}{l}\text { lart, and R } \\
\text { Indicator }\end{array}$ & de facto & & e jure Indica & \\
\hline Variable & $\begin{array}{l}\text { Total } \\
\text { Capital } \\
\text { Flows }\end{array}$ & $\begin{array}{l}\text { Lane and } \\
\text { Milesi- } \\
\text { Ferretti }\end{array}$ & $\begin{array}{l}\text { Chinn } \\
\text { and Ito }\end{array}$ & $\begin{array}{l}\text { Total } \\
\text { Capital } \\
\text { Flows }\end{array}$ & $\begin{array}{l}\text { Lane and } \\
\text { Milesi- } \\
\text { Ferretti }\end{array}$ & $\begin{array}{l}\text { Chinn } \\
\text { and Ito }\end{array}$ \\
\hline & (1) & (2) & (3) & (4) & (5) & (6) \\
\hline Financial openness & $\begin{array}{r}1.562 \\
(1.141)\end{array}$ & $\begin{array}{c}1.261 \\
(1.452)\end{array}$ & $\begin{array}{l}-0.617 \\
(0.502)\end{array}$ & $\begin{array}{l}-0.497 \\
(1.185)\end{array}$ & $\begin{array}{l}2.050 \\
(1.402)\end{array}$ & $\begin{array}{l}-1.239^{* * *} \\
(0.429)\end{array}$ \\
\hline $\begin{array}{l}\text { Stock market capitalization } \\
\text { (\% of GDP) }\end{array}$ & $\begin{array}{r}1.485^{*} \\
(0.796)\end{array}$ & $\begin{array}{c}1.341^{*} \\
(0.792)\end{array}$ & $\begin{array}{l}2.252^{* * *} \\
(0.752)\end{array}$ & $\begin{array}{l}3.028^{* * *} \\
(0.530)\end{array}$ & $\begin{array}{l}2.400^{* * *} \\
(0.439)\end{array}$ & $\begin{array}{l}3.516^{* * *} \\
(0.656)\end{array}$ \\
\hline Managed exchange rate regime & $\begin{array}{c}0.556 \\
(2.414)\end{array}$ & $\begin{array}{r}2.227 \\
(3.311)\end{array}$ & $\begin{array}{l}0.248 \\
(2.095)\end{array}$ & $\begin{array}{l}-0.377 \\
(2.181)\end{array}$ & $\begin{array}{c}1.882 \\
(2.082)\end{array}$ & $\begin{array}{l}2.579^{*} \\
(1.437)\end{array}$ \\
\hline Flexible exchange rate regime & $\begin{array}{l}-1.139 \\
(3.348)\end{array}$ & $\begin{array}{l}-0.305 \\
(5.626)\end{array}$ & $\begin{array}{l}-2.098 \\
(3.142)\end{array}$ & $\begin{array}{r}2.573 \\
(2.167)\end{array}$ & $\begin{array}{c}3.921 \\
(3.234)\end{array}$ & $\begin{array}{l}3.801^{* *} \\
(1.699)\end{array}$ \\
\hline $\begin{array}{l}\text { Free falling/dual exchange rate } \\
\text { regime }\end{array}$ & $\begin{array}{l}2.732 \\
(3.554)\end{array}$ & $\begin{array}{l}-4.519 \\
(9.062)\end{array}$ & $\begin{array}{c}1.218 \\
(2.433)\end{array}$ & $\begin{array}{r}-2.200 \\
(1.514)\end{array}$ & & \\
\hline $\begin{array}{l}\text { Financial openness } x \text { managed } \\
\text { exchange rate regime }\end{array}$ & $\begin{array}{l}-0.613 \\
(0.736)\end{array}$ & $\begin{array}{l}-0.792 \\
(0.613)\end{array}$ & $\begin{array}{l}0.118 \\
(0.411)\end{array}$ & $\begin{array}{l}0.776 \\
(0.772)\end{array}$ & $\begin{array}{l}-0.268 \\
(0.466)\end{array}$ & $\begin{array}{l}0.837^{* * *} \\
(0.248)\end{array}$ \\
\hline exchange rate regime & $\begin{array}{l}-1.054 \\
(1.090)\end{array}$ & $\begin{array}{l}-0.626 \\
(1.500)\end{array}$ & $\begin{array}{c}1.195^{* *} \\
(0.502)\end{array}$ & $\begin{array}{r}0.0147 \\
(0.873)\end{array}$ & $\begin{array}{l}-0.415 \\
(0.720)\end{array}$ & $\begin{array}{c}0.486 \\
(0.307)\end{array}$ \\
\hline $\begin{array}{l}\text { Financial openness } x \text { free } \\
\text { falling/dual exchange rate regime }\end{array}$ & $\begin{array}{l}-1.527 \\
(1.199)\end{array}$ & $\begin{array}{l}0.755 \\
(1.840)\end{array}$ & $\begin{array}{l}-0.435 \\
(0.609)\end{array}$ & & & \\
\hline managed exchange rate regime & $\begin{array}{l}0.419 \\
(0.687)\end{array}$ & $\begin{array}{c}0.578 \\
(0.631)\end{array}$ & $\begin{array}{l}-0.041 \\
(0.685)\end{array}$ & $\begin{array}{l}-0.465 \\
(0.385)\end{array}$ & $\begin{array}{c}0.007 \\
(0.365)\end{array}$ & $\begin{array}{l}-0.860^{*} \\
(0.438)\end{array}$ \\
\hline $\begin{array}{l}\text { Stock market capitallzatıon } x \\
\text { flexible exchange rate regime }\end{array}$ & $\begin{array}{c}0.780 \\
(0.837)\end{array}$ & $\begin{array}{c}0.588 \\
(0.901)\end{array}$ & $\begin{array}{c}0.069 \\
(0.904)\end{array}$ & $\begin{array}{l}-0.870^{*} \\
(0.522)\end{array}$ & $\begin{array}{l}-0.506 \\
(0.459)\end{array}$ & $\begin{array}{l}-1.244^{* *} \\
(0.516)\end{array}$ \\
\hline falling/dual exchange rate regime & $\begin{array}{c}0.003 \\
(0.756) \\
\end{array}$ & $\begin{array}{c}0.195 \\
(0.659)\end{array}$ & $\begin{array}{l}-0.795 \\
(0.820)\end{array}$ & & & \\
\hline Number of instruments & 66 & 66 & 66 & 63 & 63 & 63 \\
\hline Serial correlation test ( $p$-value) & 0.567 & 0.404 & 0.272 & 0.311 & 0.575 & 0.350 \\
\hline $\begin{array}{l}\text { Hansen test of overidentifying } \\
\text { restrictions ( } p \text {-value) }\end{array}$ & 0.059 & 0.043 & 0.108 & 0.056 & 0.072 & 0.319 \\
\hline
\end{tabular}

$\mathrm{GDP}=$ gross domestic product, IMF = International Monetary Fund.

Notes: Robust standard errors in parentheses. ${ }^{*} p<0.1,{ }^{* *} p<0.05,{ }^{* * *} p<0.01$. Control variables, including period dummy variables indicated in table 1, are included in the estimation but not reported here. Total capital flows, Lane and Milesi-Ferretti's measure of openness, and stock market capitalization are expressed in natural logarithms.

Source: Authors' estimates. 


\section{REFERENCES}

Alesina, A., V. Grilli, and G. M. Milesi-Ferretti. 1994. The Political Economy of Capital Controls. In L. Leiderman and A. Razin, eds. Capital Mobility: The Impact on Consumption, Investment, and Growth. New York: Cambridge University Press.

Arellano, M. and S. Bond. 1991. Some Tests of Specification for Panel Data: Monte Carlo Evidence and an Application to Employment Equations. Review of Economic Studies. 58 (2). pp. 277-97.

Barro, R. and J.-W. Lee. 2010. A New Data Set of Educational Attainment in the World, 1950-2010. Journal of Development Economics. 104. pp. 184-98.

Bartolini, L. and A. Drazen. 1997. When Liberal Policies Reflect External Shocks, What Do We Learn? Journal of International Economics. 42 (3-4). pp. 249-73.

Beck, T., A. Demirgüç-Kunt, and R. Levine. 2000. A New Database on Financial Development and Structure. World Bank Economic Review. 14 (3). pp. 597-605.

2009. Financial Institutions and Markets across Countries and over Time: Data and Analysis. World Bank Policy Research Working Paper. No. 4943. Washington, DC: World Bank.

Beck, T. and R. Levine. 2004. Stock Markets, Banks and Growth: Panel Evidence. Journal of Banking and Finance. 28 (3). pp. 423-42.

Beck, T., R. Levine, and N. Loayza. 2000. Finance and Sources of Growth. Journal of Financial Economics. 58 (1-2). pp. 261-300.

Bekaert, G., C. Harvey, and C. Lundblad. 2005. Does Financial Liberalization Spur Growth? Journal of Financial Economies. 77 (1). pp. 3-55.

Bosworth, B. P. and S. M. Collins. 1999. Capital Flows to Developing Economies: Implications for Saving and Investment. Brookings Papers on Economic Activity 1. Washington, DC: Brookings Institution.

Brune, N. E. and A. Guisinger, 2006. Myth or Reality? The Diffusion of Financial Liberalization in Developing Countries. ncgg.princeton.edu/IPES/2006/papers/brune_guisinger_F900_1.pdf

Bussière, M. and M. Fratzscher. 2008. Financial Openness and Growth: Short-run Gain, Long-run Pain? Review of International Economics. 16 (1). pp. 69-95.

Chinn, M. D. and H. Ito. 2008. A New Measure of Financial Openness. Journal of Comparative Policy Analysis. 10 (3). pp. 309-22.

Cihak, M., A. Demirgüç-Kunt, E. Feyen, and R. Levine. 2012. Benchmarking Financial Systems around the World. World Bank Policy Research Working Paper. No. 6175. Washington: World Bank.

Demirgüç-Kunt, A. and R. Levine. 2008. Finance, Financial Sector Policies, and Long-Run Growth. World Bank Policy Research Working Paper. No. 4469. Washington, DC: World Bank. 
Edison, H. J., M. W. Klein, L. Ricci, and T. Sloek. 2004. Capital Account Liberalization and Economic Performance: Survey and Synthesis. IMF Staff Papers. 51 (2). pp. 22-56.

Edison, H. J., R. Levine, L. Ricci, and T. Slok. 2002. International Financial Integration and Economic Growth. Journal of International Money and Finance. 21 (6). pp. 749-76.

Estrada, G., D. Park, and A. Ramayandi. 2010. Financial Development and Economic Growth in Developing Asia. ADB Economics Working Paper Series. No. 233. Manila: Asian Development Bank.

Ghosh, A. R., A.-M. Gulde, J. D. Ostry, and H. C. Wolf. 1997. Does the Nominal Exchange Rate Regime Matter? NBER Working Paper. No. 5874. Cambridge, MA: National Bureau for Economic Research.

Ilzetski, E., C. M. Reinhart, and K. S. Rogoff. 2011. The Country Chronologies and Background Material to Exchange Rate Arrangements into the 21st Century: Will the Anchor Currency Hold? personal.Ise.ac.uk/ilzetzki/data/ERA-Country_Chronologies_2011.pdf (accessed on 15 September 2014).

Jeanne, O., M. Noland, A. Subramanian, and J. Williamson. 2014. Financial Globalization and LongRun Growth: Is Asia Different? In Asian Capital Market Development and Integration. Asian Development Bank and Korea Capital Market Institute. Delhi: Oxford University Press.

Johnston, R. B. and N. T. Tamirisa. 1998. Why Do Countries Use Capital Controls? IMF Working Paper. No. 98/181. Washington, DC: International Monetary Fund.

King, R. G. and R. Levine. 1993. Finance, Entrepreneurship, and Growth: Theory and Evidence. Journal of Monetary Economics. 32 (3). pp. 513-42.

Kose, M. A., E. Prasad, K. Rogoff, and S.-J. Wei. 2009. Financial Globalization: A Reappraisal. IMF Staff Papers. 56 (1). pp. 8-62.

Lane, P. R. and G. M. Milesi-Ferretti. 2006. The External Wealth of Nations Mark II: Revised and Extended Estimates of Foreign Assets and Liabilities, 1970-2004. IMF Working Paper. No. 06/69. Washington, DC: International Monetary Fund.

- 2007. The External Wealth of Nations, Mark II: Revised and Extended Estimates of Foreign Assets and Liabilities, 1970-2004. Journal of International Economics. 73 (2). pp. 223-50.

Levine, R. and S. Zervos. 1998. Stock Markets, Banks, and Economic Growth. American Economic Review. 88 (3). pp. 537-58.

Mody, A. and A. P. Murshid. 2005. Growing Up with Capital Flows. Journal of International Economics. 65 (1). pp. 249-66. 
Obstfled, M. 2009. International Finance and Growth in Developing Countries: What Have We Learned? IMF Staff Papers. No. 56 (1). pp. 63-111. Washington, DC: International Monetary Fund.

Quinn, D. P., M. Schindler, and A. M. Toyoda. 2011. Assessing Measures of Financial Openness and Integration. IMF Economic Review. 59 (3). pp. 488-522.

Quinn, D. P. and A. M. Toyoda. 2008. Does Capital Account Liberalization Lead to Growth? Review of Financial Studies. 21 (3). pp. 1403-49.

Rajan, R. G. and L. Zingales. 1998. Financial Dependence and Growth. American Economic Review. 88 (3). pp. 559-86.

Reinhart, C. M. and K. S. Rogoff. 2004. The Modern History of Exchange Rate Arrangements: A Reinterpretation. Quarterly Journal of Economics. 119 (1). pp. 1-48.

Rodrik, D. 1998. Who Needs Capital-Account Convertibility? In Should the IMF Pursue Capital-Account Convertibility? ed. Stanley Fischer, Richard N. Cooper, Rudiger Dornbusch, Peter M. Garber, Carlos Massad, Jacques J. Polak, Dani Rodrik, and Savak S. Tarapore. Essays in International Finance May, No. 207, International Finance Section, Department of Economics, Princeton University. www.princeton.edu/ ies/IES_Essays/E207.pdf

Rojas-Suarez, L. 2008. Domestic Financial Regulations in Developing Countries: Can They Effectively Limit the Impact of Capital Account Volatility? In J. A. Ocampo and J. Stiglitz, eds. Capital Market Liberalization and Development. New York: Oxford University Press.

Schindler, M. 2009. Measuring Financial Integration: A New Data Set. IMF Staff Papers. No. 56 (1). pp. 222-38. Washington, DC: International Monetary Fund. 


\section{Financial Development, Financial Openness, and Economic Growth}

This paper examines the importance of financial development and openness. It discusses the results of an empirical analysis between both variables and economic growth. In addition to using more updated data, which extend the sample period to include some postcrisis years, the paper examines whether country characteristics and factors such as the exchange rate regime affect the finance-growth nexus.

\section{About the Asian Development Bank}

ADB's vision is an Asia and Pacific region free of poverty. Its mission is to help its developing member countries reduce poverty and improve the quality of life of their people. Despite the region's many successes, it remains home to the majority of the world's poor. $A D B$ is committed to reducing poverty through inclusive economic growth, environmentally sustainable growth, and regional integration.

Based in Manila, ADB is owned by 67 members, including 48 from the region. Its main instruments for helping its developing member countries are policy dialogue, loans, equity investments, guarantees, grants, and technical assistance. 